\title{
Element Speciation in UK Biomass Power Plant Residues Based on Composition, Mineralogy,
}

\section{Microstructure and Leaching}

Anna A. Bogush ${ }^{1,}{ }^{*}$, Julia A. Stegemann ${ }^{1}$, Richard Williams ${ }^{2}$ and lan G. Wood ${ }^{3}$

${ }^{1}$ Centre for Resource Efficiency \& the Environment (CREE), Department of Civil, Environmental \& Geomatic Engineering (CEGE), University College London (UCL), Chadwick Building, Gower Street, London E1 6QG, UK

${ }^{2}$ NERC Centre for Ecology and Hydrology (CEH), Maclean Building, Benson Lane, Crowmarsh, Gifford, Wallingford OX10 8BB, UK

${ }^{3}$ Department of Earth Sciences, University College London (UCL), Gower Street, London WC1E 6BT, UK

*Corresponding author. Tel.: +44(0)7826272095; E-mail address: $\underline{\text { a.bogush@ucl.ac.uk }}$

\section{Abstract}

Biomass ash management is an escalating issue in many countries because of increasing numbers of biomass power plants. Comprehensive characterization of biomass ashes with emphasis on element speciation, and solubility of nutrients (e.g., $\mathrm{K}$ and $\mathrm{P}$ ) and pollutants is essential for potential utilization of these residues for soil nutrition. All the UK biomass ashes investigated, whether from combustion of poultry litter, meat and bone meal, and straw, were alkaline and contained high concentrations of $\mathrm{P}, \mathrm{K}$, and $\mathrm{Ca}$. The biomass air pollution control (APC) residues were enriched in $\mathrm{K}, \mathrm{Cl}, \mathrm{S}$ and $\mathrm{Zn}$, and contained less lithophile elements, such as $\mathrm{Al}, \mathrm{Ca}, \mathrm{P}, \mathrm{Mg}, \mathrm{Si}, \mathrm{Ti}$, and $\mathrm{Ba}$, compared to the bottom ashes. P appeared in: 1) bottom ashes as apatite and other phosphates (potassium hydrogen phosphate and potassium iron phosphate in the bottom ashes from combustion of poultry litter); 2) APC residues from combustion of poultry litter as potassium sodium calcium phosphate. $\mathrm{K}$ is present mainly in sylvite, arcanite, and some phosphates. $\mathrm{Na}, \mathrm{K}, \mathrm{Cl}$, and $\mathrm{S}$ were easily leached by water from the biomass $\mathrm{APC}$ residues. However, water leaching of $\mathrm{P}, \mathrm{Ca}$, and $\mathrm{Mg}$ was very low, with leaching of $\mathrm{P}$ possibly controlled 
by hydroxyapatite. Aqueous $\mathrm{Zn}, \mathrm{Cu}$ and $\mathrm{Pb}$ appear to prevail in the form of neutral and anionic hydroxide complexes, which are toxic and easily accessible chemical forms for live organisms. Application of the poultry litter bottom ashes as a PK fertiliser in agriculture is appropriate. However, direct application of APC residues to agricultural fields is not appropriate but recovery of $\mathrm{K}$ and $\mathrm{P}$ from that material should be considered.

Keywords: Biomass; bottom ash; fly ash; APC residue; element speciation; leaching; phosphorous; potassium; fertiliser

\section{Introduction}

The combustion of biomass for heat and power generation is rising continuously because of limited availability of fossil fuels and evidence of global warming caused by $\mathrm{CO}_{2}$ emissions from fossil fuel combustion [1]. In the UK, $29 \%$ of the current 25 GWe coal-fired generating capacity will be lost after 2016 due to the stringent emission limits in the Large Combustion Plant Directive [2]. There are already 20 biomass power plants in the UK ( 1.1 GWe), and the urgent need to replace fossil fuels with renewable energy sources has led to proposals for a further 37 UK biomass power plants, which will generate $\sim 6 \mathrm{GWe}$ and result in $>2 \mathrm{Mtpa}$ of biomass ash [3,4]. According to Vassillev et al. [5], about 480 Mtpa of biomass ash, compared to $780 \mathrm{Mtpa}$ of coal ash, may be generated worldwide. Therefore, it is clear that biomass ash management is an escalating issue. In accordance with the waste hierarchy, it would be desirable to reuse or recycle these wastes. Comprehensive characterisation of biomass ashes is needed to consider their further possible application. Data published on the properties of biomass ashes are not as detailed as for ashes of coal $[6,7]$. The wide variety of fuels for biomass power plants, including forestry and agricultural crops and residues, animal residues, industrial residues, food wastes, sewage sludge, etc., as well as their use in different energy-from-waste systems [8], influence ash elemental and mineralogical composition $[5,6]$, and therefore solubility, leachability and biological availability of its components. 
The aim of this work was comprehensive characterization, including bulk and trace element composition, mineralogical and microstructural investigation and water-leaching of bottom and APC residues from combustion of three types of waste biomass: (i) poultry litter, (ii) meat and bone meal and (iii) straw, in UK biomass power plants. In a context of potential utilization of these residues for soil nutrition, the emphasis was on determining the speciation, and solubility of nutrients and pollutants. This knowledge is essential for development of appropriate, environmentally friendly and economically rational biomass ash management.

\section{Background}

\subsection{Residues from biomass combustion}

An important body of work on biomass ash, including an excellent review of the information available in the literature on biomass ash properties, has been recently carried out by Vassilev and his co-authors, which obviates the need for a full review and only key points are summarised here. Vassilev et al. [5] defined biomass as "a complex heterogeneous mixture of organic matter and, to a lesser extent, inorganic matter, containing various intimately associated solid and fluid phases with different contents and origins". Vassilev et al. [6] proposed the following classification for biomass used as a renewable energy source, with average ash chemical compositions shown in Figure 1: 1) Wood and woody biomass (WWB); 2) Herbaceous and agricultural biomass (HAB; 2.1. - Grasses and flowers; 2.2. - Straws, HAS; 2.3. - Other residues); 3) Aquatic biomass; 4) Animal and human biomass wastes (AB); 5) Contaminated biomass and industrial biomass wastes (CB); and 6) Mixed biomass (MB). Poultry litter ash can be considered as part of group $6(\mathrm{MB})$, whereas meat and bone meal falls into group $4(\mathrm{AB})$, and straw into group $2(\mathrm{HAB})$; further information for these ashes studied in the present work was not collected by Vassilev.

Also, according to Vassilev et al. [6], the ash yield after combustion of organic matter at $550-800^{\circ} \mathrm{C}$ for 86 varieties of biomass ranges from $0.1-46 \%$ (average $-6.8 \%$ ). The ash yield from biomass, which is lower than that from coal, follows the sequence: animal $>$ aquatic $>$ contaminated $>$ herbaceous and 
agricultural > wood and woody. Biomass fuels are commonly contaminated with soil and other materials, which have become mixed with the fuel during collection, harvesting, handling, storage and processing of the fuel [11], and may affect the ash content. In any case, ash yield at an industrial power plant highly depends on the combustion conditions, including the temperature, which varies between 800 and $1600^{\circ} \mathrm{C}$. There are three types of biomass ashes: 1) bottom ash, which mainly contains bigger particles that fall through the grate during combustion; 2) fly ash, which contains fine particles that are carried over by the combustion gases and fall out in various parts of the boiler and the flue gas cleaning system; 3) air pollution control residue (APCr), which is the mixture of fly ash and reagents (e.g., lime and active carbon) injected to remove pollutants in flue gas cleaning system. Classification of biomass ashes according to the European Waste Catalogue [12] is required before making a decision for further application of that waste. The following waste codes may be considered for biomass ash classification:

1) 100101 - bottom ash, slag and boiler dust (excluding boiler dust mentioned in 1001 04); 2) 1001 03 - fly ash from peat and untreated wood; 3) 100105 - calcium-based reaction wastes from flue-gas desulphurisation in solid form; 4) 100107 - calcium-based reaction wastes from flue-gas desulphurisation in sludge form; 5) 1001 18* - wastes from gas cleaning containing hazardous substances; 6) 100119 - wastes from gas cleaning other than those mentioned in 100105,100107 and 1001 18; 7) $190107^{*}$ - solid wastes from gas treatment; 8) 1901 13* - fly ash containing hazardous substances; 9) 190114 - fly ash other than those mentioned in 190113.

\subsection{Elemental composition}

The elemental composition of biomass ashes depends on the biomass resource (plant or animal, plant species or part of plants, growing processes and conditions, age of the plants, fertilizer and pesticide doses used, harvesting time, collection technique, transport, storage, pollution, processing, etc.), the biomass combustion conditions (fuel preparation, combustion technology and conditions, collection and cleaning equipment), and the transport and storage of the biomass ash [6]. Livingston [11] proposed three types of biomass ashes that were described in [5]: “1) high Si/high K/low Ca ashes 
with low fusion temperatures, including many agricultural residues; 2) low Si/low K/high Ca ashes with high fusion temperatures, including mainly woody materials; and 3) high $\mathrm{Ca}$ /high $\mathrm{P}$ ashes with low fusion temperatures, mainly from manures, poultry litters and animal wastes". Vassilev et al. [6] collected information about concentrations of major (>1.0\%, including $\mathrm{Ca}, \mathrm{K}, \mathrm{P}, \mathrm{S}, \mathrm{Mg}, \mathrm{Al}$, and $\mathrm{Si}$ ), minor $(0.1-1.0 \%$ including $\mathrm{Mn})$ and trace $(<0.1 \%$, including $\mathrm{Cu}, \mathrm{Zn}, \mathrm{Cr}$, and $\mathrm{Ni})$ elements. The potential environmental contaminants $\mathrm{Hg}, \mathrm{Cd}, \mathrm{Sb}, \mathrm{Se}, \mathrm{V}, \mathrm{Br}, \mathrm{Cr}, \mathrm{Pb}, \mathrm{Zn}$ and $\mathrm{As}$, as well as $\mathrm{Cl}$ and the nutrients $\mathrm{S}, \mathrm{K}$ and $\mathrm{Na}$, have the highest volatilization potential and are enriched in the fly ash rather than in the bottom ash [5,13-19]. Some biomass ashes, for example, from meat and bone meal (MBM), poultry litter, olive processing and sewage sludge, can contain considerable amounts of $P[20]$, which tends to accumulate in bottom ash rather than fly ash.

\subsection{Phase composition}

Vassiliev et al. [5,21] found that 291 minerals and phases have been previously identified in different biomass ashes, in comparison with 188 in coal ashes. They specified the common phases that present in biomass ashes: 1) inorganic phases (e.g., silicates, oxides and hydroxides, sulphates, phosphates, carbonates, chlorides, nitrates, glass, amorphous (non-glass) phases); 2) organic phases (e.g., cellulose, hemicellulose, lignin, char, other organic phases and minerals). The common phases (e.g., glass, char, quartz, calcite, sylvite, lime, arcanite, anhydrite, portlandite, apatite, halite, clay minerals, gypsum, amorphous (non-glass) material, etc.) identified in biomass ashes were summarized by Vassilev et al. [21]. The phase-mineral composition of biomass ashes is highly variable and strongly depends on the type of biomass fuel, combustion conditions, transport and storage of biomass ashes [21]. Vassiliev et al. [21] proposed a classification of the phases and minerals in biomass ashes by origin: 1) primary (e.g., refractory silicates, oxyhydroxides and phosphates); 2) secondary (e.g., species from all mineral classes, glass, char); 3) tertiary (e.g., carbonates, hydroxides). The phase-mineral transformations of organic and inorganic matter during biomass combustion were discussed in detail by Vassiliev et al. [21]. Also, Vassiliev et al. [5] proposed a classification of the mineral phase composition of biomass ashes. On a 
ternary diagram (shown as Figure 1 to include the results of the present work), the upper corner (Si+Al+Fe+Na+Ti oxides) mostly represents the occurrence of glass, silicates and oxyhydroxides of these elements in the biomass ashes, the left corner ( $\mathrm{Ca}+\mathrm{Mg}+\mathrm{Mn}$ oxides) mainly includes carbonates, oxyhydroxides, glass, silicates and some phosphates of these elements, and the right corner $(\mathrm{K}+\mathrm{P}+\mathrm{S}+\mathrm{Cl}$ oxides) represents phosphates, sulphates, chlorides, glass, some silicates, and carbonates of these elements $[5,6,9,10,13,21,22]$. Four chemical biomass ash types (S, C, K, and CK) are further specified into seven sub-types (with high (HA), medium (MA), and low acid (LA) tendencies) [21,22].

\subsection{Water-leaching of biomass ashes}

Literature data collected by Vassilev et al. $[5,13,22,23]$ indicate that biomass ashes can be up to $70 \%$ soluble in water, resulting in a $\mathrm{pH}$ of 4.5 to 13.4 . Water can leach the following phases from biomass ashes [5,22]: highly soluble chlorides (sylvite, halite), sulphates (arcanite, syngenite, ettringite, gypsum, bassanite, anhydrite, hexahydrite, alunite, jarosite, szomolnokite, kieserite, polyhalite), nitrates, some oxides (lime), some hydroxides (portlandite), some carbonates (calcite, dolomite, ankerite), organic minerals (calcium oxalates), a portion of phosphates (phosphorites) and silicates (calcium silicates, opal, zeolite, feldspars). The classification of biomass ashes proposed by Vassilev et al. [5] is very important in order to differentiate biomass ashes to high (e.g., K-LA, CK-LA, and C-LA sub-types), medium (e.g., S-MA, C-MA, and K-MA sub-types), and less (e.g., S-HA sub-type) water-soluble BAs categories [22]. This classification can help to assess potential environmental issues for further BAs application, and choose appropriate or potential utilization of BAs. Significant proportions (10-100\%) of elements such as $\mathrm{Ca}, \mathrm{Cd}, \mathrm{Cl}, \mathrm{Co}, \mathrm{Cr}, \mathrm{Cu}, \mathrm{K}, \mathrm{Li}, \mathrm{Mg}, \mathrm{Mn}, \mathrm{Mo}, \mathrm{Na}, \mathrm{Ni}, \mathrm{P}, \mathrm{Pb}, \mathrm{S}, \mathrm{Se}, \mathrm{Si}, \mathrm{Sr}$ and $\mathrm{Zn}$ can be leached by water from biomass ashes [5,22]. Also, Vassilev et al. [23] indicated that the nutrients and some potential pollutants can associate with the water-soluble fraction of BAs. 


\subsection{Materials}

This research was conducted with eight UK biomass ashes (approximately $5 \mathrm{~kg}$ of each samples),

including three bottom ashes and five APC residues, obtained from five UK power plants that combust waste biomass. Table 1 shows the sample identification codes, which are based on the fuel type (S indicates straw, PL indicates poultry litter, i.e., a mixture of wood shavings, straw and poultry droppings, and MBM indicates meat and bone meal) and ash type (bottom ash, BA and air pollution control residue, APCr), and combustion history. Since biomass ashes can contain hygroscopic phases, the samples were stored in air-tight containers. Representative subsamples for testing were obtained for each of the UK biomass ashes by coning and quartering. The subsamples were ground for analysis using a micronizing mill.

Figure 2 shows the appearance of the biomass ashes. The colour of these samples ranged from light grey and brown to black. Darker coloured biomass ashes generally contain char, indicating poor combustion efficiency. They include a fine sandy sample (MBM-BA), dusty fine-grained powders (SAPCr, MBM-APCr, PL1-APCr, and PL3-APCr), and mixtures of fine sandy and dusty fine-grained materials (PL2-BA, PL2-APCR, and PL3-BA). Some biomass ashes had friable agglomerated chunks with spots of black, grey, blue, brown and/or white particles.

\subsection{Methods}

The moisture content of each biomass ash sample was determined using standard method BS EN 12880:2000 [24] conducted in triplicate, and the results were averaged. The organic matter content in biomass ash was estimated by loss on ignition (LOI) at $550^{\circ} \mathrm{C}$ for $2 \mathrm{~h}$.

An energy dispersive X-ray fluorescence (EDXRF) spectrometer Spectro XLAB2000, equipped with a 400W Rh end window X- ray tube and a Si(Li) detector with a resolution of $148 \mathrm{eV}$ (1000 cps Mn Ka), was used for element analysis of a representative subsample (2-4 g of powder) of each of the 
homogenized biomass ashes. The accuracy and precision of the XRF analysis were determined by running two certified reference materials.

XRD was used to characterize the crystalline phases present in the biomass ashes. Each sample was ground with a mortar and pestle and side-loaded against a ground-glass surface into a glass-backed sample holder. XRD analyses were carried out using a high-resolution PANalytical X'pert PRO powder diffractometer. This diffractometer is equipped with a Co anode X-ray tube and an incident beam Ge monochromator, which produces a single CoK-alpha 1 line, leading to very sharp diffraction maxima. The software available includes search-match access to the International Centre for Diffraction Data (ICDD) database for phase identification. Phases in the APC residues were identified on the basis of a match for at least three main peaks with phases in the ICDD database.

The morphologies of the biomass ash particles were investigated by scanning electron microscopy (SEM) at different magnifications on a JEOL JSM-6480LV high-performance, variable-pressure analytical scanning electron microscope with secondary electron imaging (SEI) and backscattered electron imaging (BEI) detectors. More than a hundred spot-analyses were performed.

A representative subsample of each biomass ash was tested according to BS EN 12457-2:2002 [25] to characterise and assess the constituents that can be leached by water at a liquid-to-solid (L/S) ratio of $10 \mathrm{~L} / \mathrm{kg}$ without $\mathrm{pH}$ adjustment. This is a regulatory test for granular waste in the UK, and the leaching results can therefore be compared with waste acceptance criteria (WAC) for landfill [26]. This test was also used to assess the solubility of $\mathrm{K}$ and $\mathrm{P}$ in relation to possible direct application of biomass ash to land as a fertilizer. The $\mathrm{pH}$ value was measured before filtration of the leachate and analysis for the parameters of interest. The leachates were filtered using a $0.45 \mu \mathrm{m}$ membrane filter. Subsamples of the filtered leachates were acidified to $\mathrm{pH} 2$ using concentrated ultra-pure $\mathrm{HNO}_{3}$ prior to elemental analysis by inductively coupled plasma optical emission spectroscopy (ICP-OES). A second subsample, which was not acidified, was used for ion analysis by ion chromatography (IC). 
196

197

198

measured in the water leachates from the biomass ashes were used for geochemical equilibrium modelling. Equilibrium calculations were performed using the WATERQ4F computer program [27], 1991), applying the thermodynamic database from that software to calculate the solution speciation of major and selected trace elements, and the saturation indices (SI) for selected minerals that might be controlling element concentrations in the leachates. The SI gives information about whether the water was saturated $(S \mid=0)$, undersaturated $(S \mid<0)$, or supersaturated $(S \mid>0)$ with respect to a given mineral. Minerals with SIs from -1 to +1 were considered to be the potential solubility controlling minerals.

\section{Results and Discussion}

\subsection{Total element composition}

The biomass ash moisture contents varied from 0.2 to $4.2 \%$ wet mass (Table 2 ). The moisture contents of the bottom ashes were usually higher than the moisture contents of the APC residues. The biomass ash organic matter content varied from 0.04 to $5.4 \%$ (Table 2).

The total concentrations of the 24 elements measured in the biomass ashes by XRF are presented in Table 2. All biomass ashes contained high concentrations of $\mathrm{Ca}(3.4-37 \%), \mathrm{P}(2.2-9.0 \%)$ and $\mathrm{K}$ (0.9314\%). Also, the Mg concentrations were considerable in two bottom ashes (3.7\% in PL2-BA and 4.9\% in $\mathrm{PL3}-\mathrm{BA}$ ). The $\mathrm{Ca}$ and $\mathrm{P}$, and other lithophile element ( $\mathrm{Al}, \mathrm{Si}, \mathrm{Ti}, \mathrm{Ba}$ ) concentrations were higher in the bottom ashes than in the APC residues, whereas $\mathrm{K}$ and other more volatile elements $(\mathrm{Cl}, \mathrm{S}, \mathrm{Zn})$ were found to be significantly enriched in the APC residues compared to the bottom ashes. The high Ca and $\mathrm{P}$ content is characteristic of animal biomass residues, particularly poultry litter, and meat and bone meal. According to Vassilev et al. [6], the extremely high $\mathrm{K}$ content is characteristic of the HAB group and this agrees with our data for the straw ash.

The element concentrations measured in the biomass ashes can be compared with the average crustal abundances of these elements [28] and coal ash Clarke for some elements [29]. Major elements 
such as $\mathrm{Ca}, \mathrm{P}$, and $\mathrm{K}$ significantly exceed the average crustal abundance almost for all samples. The concentrations of potential pollutants, especially $\mathrm{Zn}, \mathrm{Cd}, \mathrm{Mo}, \mathrm{Pb}$, and $\mathrm{Cu}$, were also enriched in the biomass ashes. For example, $\mathrm{Zn}$ exceeded the average crustal abundance by $2.1-83$ times, $\mathrm{Cd}$ by $6-43$ times, Mo by 27-44 times (excluding MBM-BA), Pb by 1.4-34 times (excluding PL1-FA), Cu by 1.1-14 times (excluding S-FA), and As by 1.2-3.9 times (for several samples). Also, $\mathrm{P}, \mathrm{Cl}, \mathrm{Zn}, \mathrm{Cd}, \mathrm{Cu}, \mathrm{Mn}$ and $\mathrm{Pb}$ concentrations exceeded the respective coal ash Clarke values for almost all investigated biomass ashes.

For potential application of biomass ashes as a fertilizer or soil improver, comparison of element concentrations in biomass ash with limits for land application of poultry litter ash (PLA) (Table 2; [30]), the non-waste comparators such as manufactured fertiliser and/or liming agents as soil improvers (Table 2; [31,32]) may be very helpful to assist with making end-of-waste decisions. The concentration of trace elements in the poultry litter bottom ashes did not exceeded the PLA limits, excluding $\mathrm{Cu}, \mathrm{Mn}$, and Ni for PL3-BA. However, the concentrations of $\mathrm{Cd}, \mathrm{Co}, \mathrm{Mo}, \mathrm{Pb}$ (only for PL2-APCr), Zn (only for PL1APCr and PL3-APCr) in the APC residues exceeded the PLA limits. The bottom ashes have similar levels of Ca with liming agents as soil improvers but concentrations of most other elements are higher than for the comparator (Table 2). The concentration of most of elements in the APC residues exceeded the liming agent comparator. The APC residues have similar levels of $\mathrm{K}$ with manufactured fertilisers but concentrations of $\mathrm{K}$ in bottom ashes and $\mathrm{P}$ in both types of ashes are different from that comparator. Therefore, the effect of application rate should be taken into account. Regarding potential pollutants, $\mathrm{Cu}$ and $\mathrm{Co}$ exceeded the fertiliser comparator almost for all biomass ashes; Pb - for MBM-APCr and PL2.

Based on Vassilev's chemical classification for biomass ashes (2.3), all biomass bottom ashes investigated belong to the basic CK type with low acid tendency (CK-LA sub-type) and are comparable to other animal biomass ashes (Figure 1). All APC residues from the HAB and MB groups are type $K$ with 
low acid tendency (K-LA sub-type). Moreover, there is an obvious difference between biomass bottom ashes and APC residues where-by the latter drift to the right corner compared with the former.

\subsection{X-ray diffraction}

The results from XRD to identify the crystalline phases in the biomass ashes are summarised in Table 3. The bulk crystalline phases in the bottom ashes included apatite, portlandite, and quartz. Lime and disodium tricalcium silicate were identified in the bottom ash from combustion of meat and bone meal (MBM-BA). Crystalline arcanite, periclase and potassium hydrogen phosphate were found in the bottom ashes from co-combustion of poultry litter with wood and horse bedding (PL2-BA and PL3-BA). Additionally, albite was present in PL2-BA.

The biomass APC residues contained mainly sylvite, arcanite, and halite. The biomass APC residues from straw combustion (S-APCr) also contained portlandite and anhydrite. Lime was identified in MBM-APCr and PL2-APCr. Potassium sodium calcium phosphate was found in the APC residues from combustion of poultry litter (PL1-APCr, PL2-APCr and PL3-APCr). The biomass APC residues from straw combustion also contains portlandite and calcium sulphate hydrate. Periclase was present in PL2-BA, PL2-APCr, and PL3-BA as well as disodium tricalcium silicate - in MBM-BA. A trace of calcite was found in some bottom and APC residues (Table 3). The XRD diffractograms also show the presence of some amorphous material in biomass ashes as indicated by the background around $30-40^{\circ}$ Two-Theta and a lack of sharp diffraction peaks. 
4.3. Microstructure and local chemical composition of the bottom ashes by scanning electron

\section{microscopy with energy dispersive x-ray Spectroscopy}

\subsubsection{Biomass bottom ashes}

The three biomass bottom ashes examined (MBM-BA, PL2-BA, and PL3-BA) mainly contained unshaped particles (up to $1 \mathrm{~mm}$ ), aggregates and fine materials (Figure 3). Some spherical particles were also identified.

The unshaped sub-smooth particles, which were abundantly present in the biomass bottom ashes, consisted of calcium phosphate (probably apatite) with impurities of $\mathrm{Na}, \mathrm{Mg}, \mathrm{K}, \mathrm{Si}, \mathrm{Al}, \mathrm{S}$ and $\mathrm{Cl}$ (Figure 4a, point and spectrum 1). Fine phases on the surfaces of the unshaped particles had a similar composition (Figure 4b, point and spectrum 2).

Cubic and unshaped aggregates had a similar composition to the unshaped sub-smooth particles, including also Fe (Figure 5a, point and spectrum 1, and point and spectrum 2). A monodisperse aggregate contained fine particles that consisted of $\mathrm{Ca}$ and $\mathrm{O}$ (probably $\mathrm{CaO}$ or $\mathrm{Ca}(\mathrm{OH})_{2}$ ) with impurities of $\mathrm{Mg}$ and $\mathrm{P}$ (Figure $5 \mathrm{~b}$, point and spectrum 3).

Spherical particles $(50-150 \mu \mathrm{m})$ again seemed to be mainly calcium phosphate (Figure 6a, spectrum 1). The fine phases on the surface of the spherical particle were ( $\mathrm{Ca}, \mathrm{Mg}$ ) phosphates, $\mathrm{NaCl}$, and $\mathrm{K}_{2} \mathrm{SO}_{4}$ (Figure $6 \mathrm{~b}$ and $\mathrm{c}$, spectrum 2, 3, and 4).

\subsubsection{Biomass APC residues}

The morphologies of the five different biomass APC residues examined (S-APCr, PL1-APCr, MBMAPCr, PL2-APCr, and PL3-APCr) were quite different (Figure 7), and may depend on the biomass type, combustion technology and conditions, and air pollution control systems.

S-APCr mainly contained fine phases $(<1 \mu \mathrm{m})$ and unburnt straw residues $(200-300 \mu \mathrm{m})$ with a few glassy particles. Unburnt straw residue consisted of $\mathrm{C}, \mathrm{K}, \mathrm{Ca}, \mathrm{Cl}, \mathrm{P}$ and $\mathrm{Si}$ as major elements, with impurities of $\mathrm{Na}, \mathrm{Mg}, \mathrm{Al}, \mathrm{Cu}$ and $\mathrm{S}$. This biomass ash contained a lot of very fine-grained material, mainly composed of $\mathrm{K}, \mathrm{Ca}, \mathrm{Cl}$ and $\mathrm{P}$. 
to $150 \mu \mathrm{m}$ ) particles, aggregates and fine phases (Figure 7). The unshaped and spherical particles were covered by fine phases of $\mathrm{KCl}$ and $\mathrm{K}_{2} \mathrm{SO}_{4}$ (Figure 8, points and spectra 1 and 2). This particular sample contained many fine spherical particles (about 20-35 $\mu \mathrm{m}$ ), which are potassium, calcium phosphates. These spherical particles are covered and/or cemented by $\mathrm{NaCl}$ and $\mathrm{K}_{2} \mathrm{SO}_{4}$.

MBM-APCr (Figure 9) includes unshaped particles (up to $300 \mu \mathrm{m}$ ), aggregates, sub-spheres and fine materials. The sub-spherical particles are calcium phosphate, decorated by fine phases of $\mathrm{NaCl}$ and potatssium (sodium) sulphates. Also, open-work crusts mainly consist of $\mathrm{Na}, \mathrm{P}, \mathrm{Cl}$, and $\mathrm{O}$ (probably $\mathrm{Na}$ phosphate chloride) (Figure 9, point and spectrum 2).

PL2-APCr was full of spherical particles (50-250 $\mu \mathrm{m})$, unshaped and slaggy phases (50-400 $\mu \mathrm{m})$. Smooth spherical particles mainly contained K, Ca, Mg, P, Si, and O (Figure 10, point and spectrum 1). Another spherical particle seemed to be an empty aggregate, with a "puzzle" surface structure. Pieces of the puzzle have different shapes and colour tones in backscattering mode. Bright and dark parts of the surface reflect variability in composition. For example, some puzzle pieces consist of potassium (calcium, magnesium) phosphates with different impurities, some with $\mathrm{Na}$ and $\mathrm{Cl}$ (Figure 10, point and spectrum 2), others with S and/or Si. Some quartz particles $(100-200 \mu \mathrm{m})$ with smooth, angular and conchoidal fractures were found in this sample. Unshaped and porous particles varying in size from 20 to $300 \mu \mathrm{m}$ are mostly likely calcium, potassium phosphate.

PL3-APCr mainly contained unshaped particles $(20-150 \mu \mathrm{m})$ and fine phases (Figure 7). The unshaped (rounded, oblong, sub-smooth with dirt-like decoration) particles mainly consisted of $\mathrm{K}, \mathrm{Ca}$, $\mathrm{Na}, \mathrm{Mg}, \mathrm{P}$ and S. A variety of fine phases with different morphologies and compositions were observed. For instance, 2-5 $\mu \mathrm{m}$ fine-grained phases consisted mainly of $\mathrm{K}, \mathrm{Na}, \mathrm{Cl}, \mathrm{S}, \mathrm{P}$, and $\mathrm{O}$ (Figure 11, point 1). $1 \mu \mathrm{m}$ rounded plate-like fine particles form a foam structure and were consisted mainly of $\mathrm{K}, \mathrm{Na}, \mathrm{Cl}$, and $\mathrm{P}$ (Figure 11, point 2). Prismatic crystals consisted of $\mathrm{Na}, \mathrm{Cl}$, and $\mathrm{P}$ were found throughout the fine material (Figure 11, point 3). 


\subsection{Leachability of biomass ashes in water}

The $\mathrm{pH}$ of the water-based leachates according to BS EN 12457-2:2002 was high due to the CaO or $\mathrm{Ca}(\mathrm{OH})_{2}$ in these samples (identified by XRD, Table 3 ) and varied from 11.32 to 12.78 (Table 4). It should be noted that a saturated solution of $\mathrm{Ca}(\mathrm{OH})_{2}$ has a $\mathrm{pH}$ of about 12.4 . The low $\mathrm{pH}$ value was associated with sample PL3-APCr, which showed neither $\mathrm{Ca}(\mathrm{OH})_{2}$ and $\mathrm{CaO}$ by XRD and had the lowest

Ca value of all the samples (Table 2). The presence of alkali oxides/hydroxides may increase the $\mathrm{pH}$, but XRD showed the alkalis to be speciated predominantly as neutral salts.

Element concentrations leached from the biomass ashes are shown together with the Waste Acceptance Criteria (WAC) for landfilling of inert waste in Table 4. Values that exceed the WAC have been shaded. The water-leached concentrations of $\mathrm{Cl}$ and $\mathrm{SO}_{4}{ }^{2-}$ exceed the WAC for inert waste for all of the biomass ashes. However, $\mathrm{Cl}$ concentrations of the water leachates from the biomass APC residues also exceed the WAC for hazardous waste $(\mathrm{Cl}>2.5 \mathrm{wt} . \%)$. It can be seen that all the Mo leachate concentrations, and all the Pb leachate concentrations except S-APCr, exceed the WAC for inert waste, as do all the $\mathrm{Zn}$ leachate concentrations from the APC residues. $\mathrm{Cu}$ concentrations also exceed the WAC for inert waste for some biomass ashes (see Table 4).

The water-soluble fractions from the biomass bottom ashes varied from 1.0 to $8.4 \%$. However, the water-soluble fractions from the biomass APC residues were quite high and ranged from 33.8 to 36.7\%. It can be seen that a higher proportion of $\mathrm{Cl}$ could be leached by water at $\mathrm{L} / \mathrm{S}=10$ from the APC residues (up to $74 \%$ ) than from the bottom ashes (up to $51 \%$ ). Cl solubility in water may be limited by its uptake in some phases, such as apatite, which was shown as to be a dominant phase in the bottom ashes. S is leached relatively easily from biomass ashes (38-55\%), which is consistent with identification of soluble arcanite as a dominant phase by XRD in most biomass ashes. In contrast to the biomass bottom ashes, almost all $\mathrm{Na}$ (up to 96\%) and high proportions of $\mathrm{K}$ (up to $84 \%$ ) could be leached from the biomass APC residues by water. A lower proportion of $K$ than $\mathrm{Na}$ leached suggests that $K$ is substituted in mineral phases with lower solubility (probably phosphate phases and aluminosilicates). 
The water-soluble fractions of $\mathrm{P}, \mathrm{Ca}$, and $\mathrm{Mg}$ are very low and range from 0.004 to $1.4 \%$ for $\mathrm{P}$, from 0.01 to $2.7 \%$ for $\mathrm{Ca}$, and from 0.01 to $3.7 \%$ for $\mathrm{Mg}$. However, the higher concentration of $\mathrm{P}$ was leached from APC residues from poultry litter incineration due to presence of mineral phases with higher solubility (probably potassium sodium calcium phosphate and potassium hydrogen phosphate).

\subsection{Element speciation in water-leachates of biomass ashes}

Table 5 presents the calculated distributions of selected aqueous element species (\%), and Table 6 the saturation indices $(\mathrm{SI})$ for hydroxyapatite and $\mathrm{Pb}(\mathrm{OH})_{2}$, for the water leachates from the biomass ashes.

Table 5 shows that sodium and potassium are mainly present as free ions $\left(\mathrm{Na}^{+}, \mathrm{K}^{+}\right)$, and less than $1.1 \%$ of sulphate is complexed, in the water leachates of all the biomass ashes. Fe and Al prevail as anionic hydroxide complexes $\left(\mathrm{Fe}(\mathrm{OH})_{4}{ }^{-}, \mathrm{Al}(\mathrm{OH})_{4}^{-}\right)$. Ca speciation in the leachates varies; the simple aqua-ion $\left(\mathrm{Ca}^{2+}\right)$ dominates, but significant proportions are complexed with phosphate and/or sulphate $\left(\mathrm{CaPO}_{4}{ }^{-}, \mathrm{CaSO}_{4}{ }^{\circ}\right)$. Magnesium is mainly present as the cationic hydroxide complex $\left(\mathrm{MgOH}^{+}\right)$and percentages of the simple ion $\left(\mathrm{Mg}^{2+}\right)$ and anionic phosphate $\left(\mathrm{MgPO}_{4}{ }^{-}\right)$are also significant.

As a consequence of the alkaline $\mathrm{pH}$, geochemical modelling shows the amphoteric contaminants $\mathrm{Zn}, \mathrm{Pb}$ and $\mathrm{Cu}$ to prevail in the form of neutral and anionic hydroxide complexes (Table 5). In fact, $\mathrm{Cu}$ may be complexed with dissolved organic matter [33], which was not taken into account in the modelling.

The toxicity and bioavailability of an element are strictly related to the chemical forms in which it occurs [34]. The most toxic and bioavailable chemical forms of elements such as $\mathrm{Zn}, \mathrm{Pb}, \mathrm{Cu}, \mathrm{Cd}$, and $\mathrm{Ni}$ are aqua-ions $\left(\mathrm{Me}^{2+}\right)$ and simple complexes with inorganic anions [35].

The saturation indices in Table 6 suggest that hydroxyapatite may control solubility of $P$, and lead hydroxide may control leachate concentrations of $\mathrm{Pb}$, for most of the biomass ashes. Brucite $\left(\mathrm{Mg}(\mathrm{OH})_{2}\right)$ altered from periclase identified in the ashes by XRD can be considered as the potential solubility controlling mineral for Mg. Copper and zinc were undersaturated with respect to their 
oxides/hydroxides, and substitution of elements into the bulk mineral phases may control the leachate concentrations of these and other elements, but it is difficult to take this into account in the modelling.

\section{Conclusions}

All the UK biomass ashes investigated, whether from combustion of poultry litter, meat and bone meal, and straw, were alkaline and contained high concentrations of $\mathrm{P}, \mathrm{K}$, and $\mathrm{Ca}$. $\mathrm{Mg}$ concentrations were also considerable in the poultry litter bottom ashes. The biomass bottom ashes belong to the CK type with low acid tendency. All APC residues belonging to HAB and MB groups are K type with low acid tendency. The biomass APC residues were enriched in the more volatile elements, such as $\mathrm{Cl}, \mathrm{S}, \mathrm{K}$ and $\mathrm{Zn}$, and contained less lithophile elements, such as $\mathrm{Al}, \mathrm{Ca}, \mathrm{P}, \mathrm{Mg}, \mathrm{Si}, \mathrm{Ti}$, and $\mathrm{Ba}$, compared to the bottom ashes. The concentrations of potential pollutants, especially $\mathrm{Zn}, \mathrm{Cd}, \mathrm{Mo}, \mathrm{Pb}$, and $\mathrm{Cu}$ were enriched in all the biomass ashes, especially in the APC residues compared to average crustal abundance and coal ash Clarkes.

The mineral phase composition of the investigated biomass ashes was complex. The bulk crystalline phases in the bottom biomass ashes included quartz, portlandite, apatite (all bottom ashes), and other phosphates (potassium hydrogen phosphate and potassium iron phosphate in the bottom ashes from combustion of poultry litter). Biomass APC residues contained mainly sylvite, arcanite, halite and lime. Potassium sodium calcium phosphate was identified in the APC residues from combustion of poultry litter. The XRD patterns suggested the presence of amorphous phases which can influence to element leachability.

In general, all the UK biomass bottom ashes were found to have a similar morphology, being composed of unshaped particles (up to $1 \mathrm{~mm}$ ), aggregates and fine materials with minor amounts of spherical particles. However, the biomass APC residues were found to have different morphologies, which may depend on the type of biomass, combustion and residue collection technology and conditions, and particularly cleaning process. 
APC residues, which had high water-soluble fractions compared to the biomass bottom ashes. However, water leaching of $\mathrm{P}, \mathrm{Ca}$, and $\mathrm{Mg}$ was very low, with leaching of $\mathrm{P}$ possibly controlled by hydroxyapatite. Leaching of $\mathrm{Cl}, \mathrm{S}, \mathrm{Pb}, \mathrm{Cu}, \mathrm{Co}, \mathrm{Mo}$ and $\mathrm{Zn}$ in water exceeded the WAC for landfilling as inert waste. Aqueous $\mathrm{Zn}, \mathrm{Cu}$ and $\mathrm{Pb}$ appear to prevail in the form of neutral and anionic hydroxide complexes, which are toxic and easily accessible chemical forms for live organisms.

\section{Recommendations and further investigation}

As all biomass ashes investigated contain significant quantities of valuable potassium and phosphorus, it is not sustainable or rational to deposit them in landfills. Application of the poultry litter bottom ashes as a PK fertiliser in agriculture is appropriate. However, direct application of APC residues to agricultural fields is not appropriate because of the significant concentrations of potentially harmful elements and water-soluble $\mathrm{Cl}$-bearing phases (can cause soil salination), which exceed levels in Environment Agency Material Comparators for fertilizers and soil improvers. Also, the availability of phosphorus from biomass ashes to plants is known to be low [36]. Therefore, recovery of $\mathrm{K}$ and $\mathrm{P}$ from the biomass ashes should be considered.

Whereas significant amounts of K can be simply extracted by water with L/S 10 from the biomass APC residues, water-leachability of $P$ from the biomass bottom ashes is very low ( $<1.4 w t . \%)$. Therefore, development of a process for $\mathrm{P}$ extraction or increasing its phytoavailability (for some biomass ashes with low potential toxic element concentrations) is recommended.

\section{Acknowledgements}

The authors gratefully acknowledge the valuable assistance of the following people:

- Rob Carroll at the UK Quality Ash Association, and Mark Westwood from Fibrophos, for assistance in obtaining biomass ash samples.

- Jim Davy in the UCL Earth Sciences, for support with the SEM/EDS analysis;

- Judith Zhou for support in the UCL CEGE laboratory; 
- Janet Hope and Kevin Roe in the Department of Geography (UCL), for support with the XRF analysis.

This work was funded by a UCL “Outgoing” Postdoctoral Mobility Award.

\section{References}

[1] European Biomass Association. AEBIOM Statistical Report - European Bioenergy Outlook. Brussels; 2015.

[2] Directive 2001/80/EC of the European Union Parliament and the Council on the limitation of emissions of certain pollutants into the air from large combustion plants, European Union, October 23, 2001.

[3] Biomass Energy Centre. UK biomass power stations. Version 1.4. Crown Copyright; 2013. $<w w w . b i o m a s s e n e r g y c e n t r e . o r g . u k>$.

[4] Ernsting A. Sustainable Biomass: A Modern Myth, Biofuelwatch; 2012.

[5] Vassilev SV, Baxter D, Andersen LK, Vassileva CG. An overview of the composition and application of biomass ash. Part 1. Phase-mineral and chemical composition and classification. Fuel 2013;105:40-76.

[6] Vassilev SV, Baxter D, Andersen LK, Vassileva CG. An overview of the chemical composition of biomass. Fuel 2010;89:913-933.

[7] Demeyer A, Voundi Nkana VJC, Verloo MG. Characteristics of wood ash and influence on soil properties and nutrient uptake: An overview. Biores. Technol. 2001;77:287-295.

[8] Pels JR, Nie DS, Kiel JHA. Utilization ashes from biomass combustion and gasification. In the presiding of the $14^{\text {th }}$ European Biomass Conference and Exhibition, Paris, France, 17-21 October 2005:182-197.

[9] Vassilev SV, Vassileva CG. A new approach for the combined chemical and mineral classification of the inorganic matter in coal. 1. Chemical and mineral classification systems. Fuel 2009;88:235-245. 
437

438

inorganic phase composition of biomass. Fuel 2012;94:1-33.

[11] Livingston WR. Biomass ash characteristics and behaviour in combustion systems. IEA Task 32/Thermalnet Workshop, Glasgow, September; 2006. (presentation)

[12] European Commission Decision 2000/532/EC of 3 May 2000 replacing Decision 94/3/EC establishing a list of wastes pursuant to Article 1(a) of Council Directive 75/442/EEC on waste and Council Decision 94/904/EC establishing a list of hazardous waste pursuant to Article 1(4) of Council Directive 91/689/EEC on hazardous waste.

[13] Vassilev SV, Baxter D, Andersen LK, Vassileva CG. An overview of the composition and application of biomass ash. Part 2. Potential utilisation, technological and ecological advantages and challenges. Fuel 2013;105:19-39.

[14] Miles TR, Miles JTR, Baxter LL, Bryers RW, Jenkins BM, Oden LL. Boiler deposits from firing biomass fuels. Biomass Bioenergy 1996;10:125-138.

[15] Misra MK, Ragland KW, Baker AJ. Wood ash composition as a function of furnace temperature. Biomass Bioenergy 1993;4:103-116.

[16] Obernberger I, Biedermann F, Widmann W, Riedl R. Concentrations of inorganic elements in biomass fuels and recovery in the different ash fractions. Biomass Bioenergy 1997;12:211-224.

[17] Arvelakis S, Jensen PA, Dam-Johansen K. Simultaneous thermal analysis (STA) on ash from high-alkali biomass. Energy Fuels 2004;18:1066-1076.

[18] Frandsen FJ, van Lith SC, Korbee R, Yrjas P, Backman R, Obernberger I, Brunner T, Joller M. Quantification of the release of inorganic elements from biofuels. Fuel Process Technol 2007;88:11181128.

[19] Thy P, Jenkins BM. Mercury in biomass feedstock and combustion residuals. Water Air Soil Poll 2010;209:429-437. 
461

462

463

464

465

466

467

468

469

470

471

472

473

474

475

476

477

478

479

480

481

482

483

Sustainable Energy Reviews 2011;15:3588-3602.

[21] Vassilev SV, Baxter D, Vassileva CG. An overview of the behaviour of biomass during combustion: Part I. Phase-mineral transformations of organic and inorganic matter. Fuel 2013;112:391-449.

[22] Vassilev SV, Baxter D, Vassileva CG. An overview of the behaviour of biomass during combustion: Part II. Ash fusion and ash formation mechanisms of biomass types. Fuel 2014;117:152183.

[23] Vassilev SV, Vassileva CG, Baxter D. Trace element concentrations and associations in some biomass ashes. Fuel 2014;129:292-313.

[24] BS EN 12880:2000. Characterization of sludges - Determination of dry residue and water content.

[25] BS EN 12457-2:2002. Characterisation of waste - Leaching - Compliance test for leaching of granular waste materials and sludges - Part 2: One stage batch test at a liquid to solid ratio of $10 \mathrm{l} / \mathrm{kg}$ for materials with particle size below $4 \mathrm{~mm}$ (without or with size reduction).

[26] Council Decision 2003/33/EC of 19th December 2002 establishing criteria and procedures for the acceptance of waste at landfills pursuant to Article 16 of and Annex II to Directive 1999/31.

[27] Ball JW, Nordstrom DK. User's manual for WATERQ4F, with revised thermodynamic date base and test cases for calculating speciation of major, trace, and redox elements in natural waters. Menlo Park; 1991.

[28] Taylor SR. Abundance of chemical elements in the continental crust: a new table. Geochim. et Cosmochim. Acta 1964;28:1273-1285.

[29] Ketris MP, Yudovich YE. Estimations of Clarkes for carbonaceous biolithes: world averages for trace elements in black shales and coals. Int J Coal Geol 2009;78:135-48. 
485 the incineration of poultry litter, feathers and straw. Quality Protocol. Environmental Agency, UK; 4862012.

[31] EA. Material comparators for end-of-waste decisions. Materials applied to land: manufactured fertilisers. Environmental Agency, Report -SC130040/R14, Version 2, Bristol, UK; 2016.

[32] EA. Material comparators for end-of-waste decisions. Materials applied to land: soil improver. Environmental Agency, Report - SC130040/R2, Version 2, Bristol, UK; 2016b.

[33] McBride M, Sauve S, Hendershot W. Solubility control of $\mathrm{Cu}, \mathrm{Zn}, \mathrm{Cd}$ and $\mathrm{Pb}$ in contaminated soils, European Journal of Soil Science 1997;48(2):337-346.

[34] Caroli S. Element speciation in bioinorganic chemistry. New York, John Wiley \& Sons, Inc.; 4941996.

[35] Budnikov HC. Heavy metals in ecological monitoring of water systems. Soros Educational 496 Journal 1998;5:23-29.

[36] Hogue BA, Inglett PW. Nutrient release from combustion residues of two contrasting 498 herbaceous vegetation types. Science of the Total Environment 2012;431:9-19. 
Table 1. UK biomass ashes used in this work

\begin{tabular}{lccccc}
\hline Sample Code & Combustion system & $\begin{array}{c}\text { Combustion } \\
\text { Temperature } \\
\left({ }^{\circ} \mathrm{C}\right)\end{array}$ & $\begin{array}{c}\text { Bottom ash } \\
\text { discharge } \\
\text { technology }\end{array}$ & $\begin{array}{c}\text { Flue gas } \\
\text { cleaning } \\
\text { technology }\end{array}$ & $\begin{array}{c}\text { Biomass group based on } \\
\text { Vassilev et al. [5] }\end{array}$ \\
\hline PL1-APCr & FBI & 850 & DS & AB \\
\hline $\begin{array}{l}\text { PL2-BA } \\
\text { PL2-APCr }\end{array}$ & GI & 850 & DD & MB \\
\hline $\begin{array}{l}\text { PL3-BA } \\
\text { PL3-APCr }\end{array}$ & GI & 850 & DD & DS & MB \\
\hline $\begin{array}{l}\text { MBM-BA } \\
\text { MBM-APCr }\end{array}$ & GI & 850 & DD & DS & AB \\
\hline S-APCr & GI & 850 & DS & AB \\
\hline
\end{tabular}

$\mathrm{FBI}$ - fluidized bed incinerator; GI - grate incinerator; DD - dry discharge; DS - dry scrubbing

Table 2. Compositions of UK biomass bottom ashes (BA) and air pollution control residue (APCr) determined by X-ray Fluorescence (mg/kg dry mass, unless otherwise indicated; NA indicates that a parameter was not available; $>1 \%$ - major; $0.1-1 \%$ - minor; $<0.1-$ trace element)

\begin{tabular}{|c|c|c|c|c|c|c|c|c|c|c|c|c|c|}
\hline \multirow[t]{2}{*}{ Element } & \multirow{2}{*}{$\begin{array}{c}\mathrm{S}- \\
\mathrm{APCr}\end{array}$} & \multirow{2}{*}{$\begin{array}{l}\text { PL1- } \\
\text { APCr }\end{array}$} & \multicolumn{2}{|c|}{ MBM } & \multicolumn{2}{|c|}{ PL2 } & \multicolumn{2}{|c|}{ PL3 } & \multirow{2}{*}{$\begin{array}{c}\text { Average } \\
\text { crustal } \\
\text { abundance } \\
{[28]}\end{array}$} & \multirow{2}{*}{$\begin{array}{c}\text { Coal ash } \\
\text { Clarke [29] }\end{array}$} & \multirow{2}{*}{$\begin{array}{c}\text { Upper limit } \\
\text { for PLA used } \\
\text { as a fertiliser } \\
{[30]}\end{array}$} & \multirow{2}{*}{$\begin{array}{l}\text { manufactured } \\
\text { fertilisers [31] }\end{array}$} & \multirow{2}{*}{$\begin{array}{c}\text { soil improver } \\
\text { (liming materials) } \\
{[32]}\end{array}$} \\
\hline & & & BA & $\mathrm{APCr}$ & BA & $\mathrm{APCr}$ & $\mathrm{BA}$ & $\mathrm{APCr}$ & & & & & \\
\hline $\mathrm{Al}, \%$ & 0.04 & 0.096 & 0.3 & 0.095 & 0.16 & 0.11 & 0.32 & 0.046 & 8.23 & - & - & - & - \\
\hline As & 1.3 & 1.8 & $<0.6$ & 2.2 & 3.8 & 5.9 & $<0.8$ & 2.7 & 1.5 & 47 & 17 & $8.6-18.6$ & $1.0-16$ \\
\hline $\mathrm{Ba}$ & 24 & 170 & 180 & 120 & 400 & 180 & 210 & 60 & 425 & 940 & - & - & - \\
\hline $\mathrm{Ca}, \%$ & 13 & 8.5 & 37 & 13 & 19 & 8.4 & 18 & 3.4 & 4.15 & - & - & - & $21-41$ \\
\hline $\mathrm{Cd}$ & 3.3 & 5.0 & 8.5 & 4.5 & 1.3 & 2.0 & 1.2 & 6.3 & 0.2 & 1.2 & 3.0 & $13.6-30.6$ & $0.2-4.0$ \\
\hline Co & 2.5 & 22 & 16 & 15 & 7.2 & 26 & 11 & 12 & 25 & 32 & 11 & $0.5-9.4$ & $0.22-2.0$ \\
\hline $\mathrm{Cu}$ & 43 & 540 & 61 & 130 & 530 & 500 & 770 & 450 & 55 & 92 & 596 & $25-56$ & $1.3-20$ \\
\hline $\mathrm{Cr}$ & 12 & $<7.0$ & 34 & 55 & $<7.0$ & $<7.0$ & $<7.0$ & $<7.0$ & $\underline{35}$ & 100 & 31 & $115-360$ & $0.62-11$ \\
\hline $\mathrm{Fe}, \%$ & 0.021 & 0.37 & 0.37 & 0.34 & 0.8 & 0.39 & 0.65 & 0.22 & $0 . \overline{563}$ & - & - & - & $0.06-1.3$ \\
\hline$K, \%$ & 14 & 13 & 0.93 & 8.3 & 5.7 & 11 & 6.1 & 13 & 2.09 & - & - & $11-20$ & $0.014-0.13$ \\
\hline $\mathrm{Mg}, \%$ & 0.17 & 1.6 & 0.4 & 0.26 & 3.7 & 1.5 & 4.9 & 0.66 & 2.33 & - & - & - & $0.11-13$ \\
\hline $\mathrm{Mn}, \%$ & 0.015 & 0.24 & 0.016 & 0.017 & 0.35 & 0.21 & 0.43 & 0.14 & 0.095 & 0.049 & 0.35 & - & $0.011-0.23$ \\
\hline
\end{tabular}




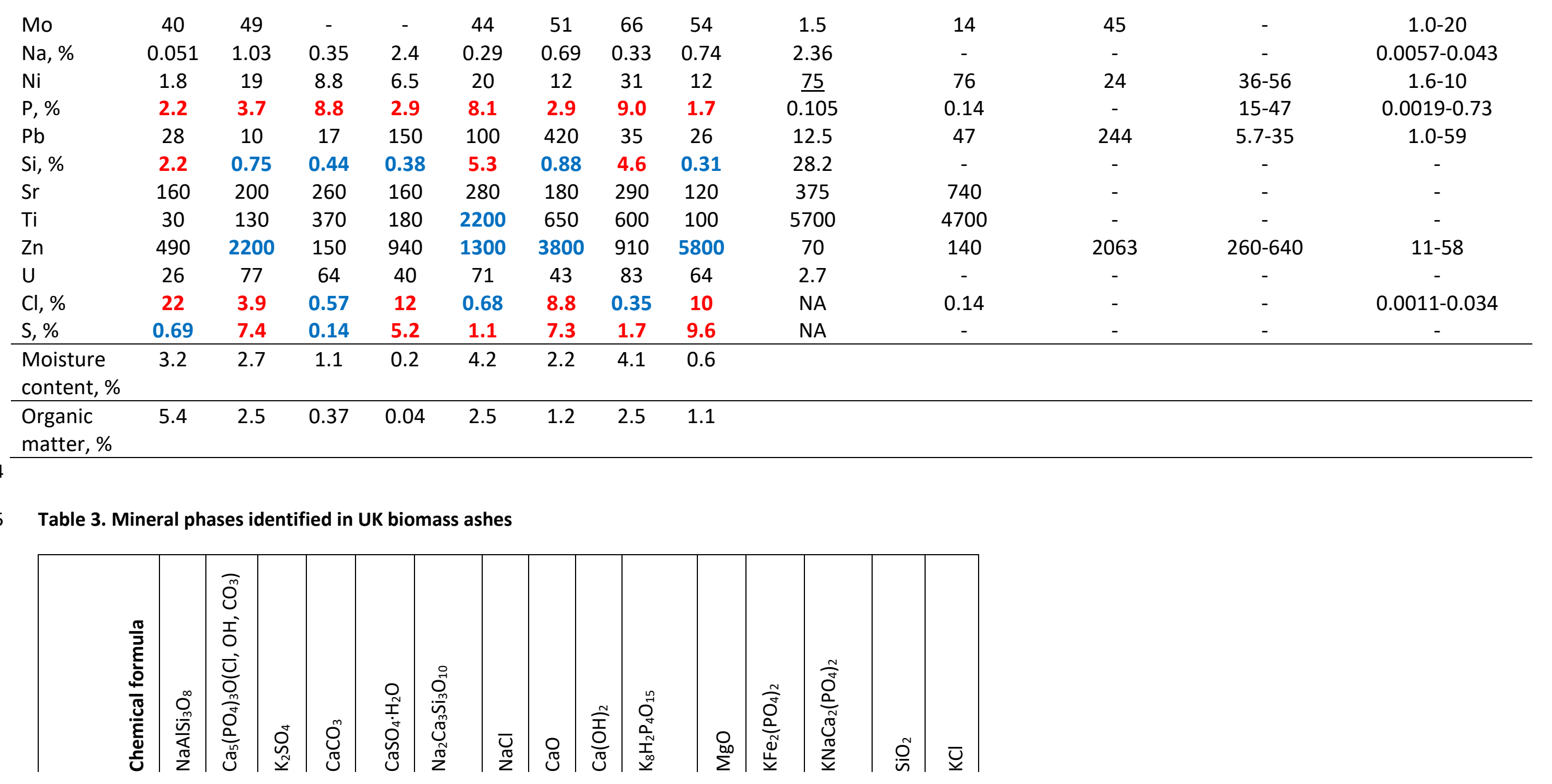




\begin{tabular}{|c|c|c|c|c|c|c|c|c|c|c|c|c|c|c|c|}
\hline 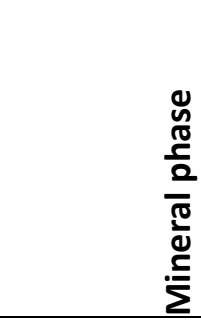 & 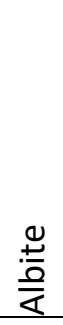 & 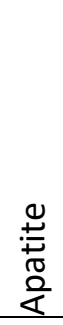 & 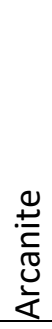 & $\frac{\stackrel{ \pm}{0}}{\frac{0}{0}}$ & 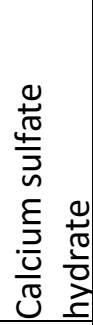 & 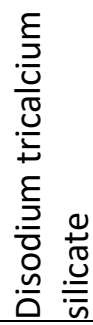 & 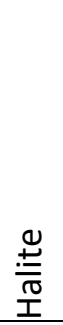 & $\stackrel{\mathscr{e}}{. ٍ}$ & 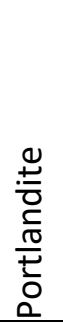 & 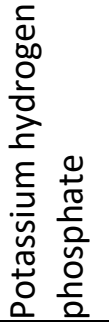 & 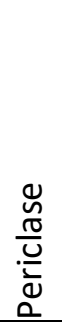 & 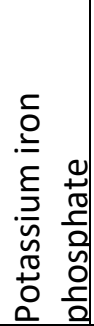 & 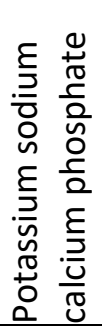 & $\begin{array}{l}\frac{N}{0} \\
\frac{0}{\sigma}\end{array}$ & $\stackrel{\stackrel{0}{2}}{\frac{5}{2}}$ \\
\hline Sample & al & ap & ar & $\mathrm{ca}$ & CS & ds & $\mathrm{h}$ & 1 & $p$ & $\mathrm{ph}$ & $\mathrm{pr}$ & $\mathrm{pi}$ & $\mathrm{ps}$ & $q$ & $\mathrm{~s}$ \\
\hline $\begin{array}{l}\text { S-APCr } \\
\text { PL1-APCr }\end{array}$ & & + & $\begin{array}{l}+ \\
+\end{array}$ & + & + & & & & $\begin{array}{l}+ \\
+\end{array}$ & & & & + & & $\begin{array}{l}+ \\
+\end{array}$ \\
\hline MBM-BA & & + & & + & & + & & + & + & & & & & + & \\
\hline MBM-APCr & & + & & + & & + & + & + & & & & & & & \\
\hline PL2-BA & + & + & + & + & & & & & + & + & + & & & + & \\
\hline PL2-APCr & & & + & & & & + & + & & & + & & + & & + \\
\hline PL3-BA & & + & + & + & & & & & + & + & + & + & & + & \\
\hline PL3-APCr & & & + & & & & + & & & & & & & & + \\
\hline
\end{tabular}

Table 4. Element concentrations leached from UK biomass ashes with water according to BS EN 12457-2:2002 and UK criteria for acceptance of granular waste (WAC) to inert landfill (mg leached/kg of dry solid)

\begin{tabular}{|c|c|c|c|c|c|c|c|c|c|}
\hline \multirow[b]{2}{*}{ Element } & \multirow{2}{*}{$\begin{array}{c}\text { S- } \\
\text { APCr }\end{array}$} & \multirow{2}{*}{$\begin{array}{l}\text { PL1- } \\
\text { APCr }\end{array}$} & \multicolumn{2}{|c|}{ MBM } & \multicolumn{2}{|c|}{ PL2 } & \multicolumn{2}{|c|}{ PL3 } & \multirow{2}{*}{$\begin{array}{c}\text { WAC for } \\
\text { granular waste } \\
\text { to inert landfill } \\
{[26]}\end{array}$} \\
\hline & & & BA & $\mathrm{APCr}$ & $\mathrm{BA}$ & $\mathrm{APCr}$ & BA & $\mathrm{APCr}$ & \\
\hline $\mathrm{pH}$ & 12.68 & 11.54 & 12.22 & 12.4 & 12.78 & 12.27 & 12.59 & 11.32 & - \\
\hline Al & 1.6 & 6.0 & 0.4 & 68 & 10 & 60 & 4.7 & 1.4 & - \\
\hline $\mathrm{Ba}$ & 1.4 & $<0.01$ & 5.3 & 5.0 & 0.3 & 0.1 & 0.01 & $<0.01$ & 20 \\
\hline $\mathrm{Ca}$ & 13 & 12 & 220 & 280 & 150 & 20 & 20 & 80 & 20 \\
\hline $\mathrm{Cd}$ & $<0.01$ & $<0.01$ & $<0.01$ & $<0.01$ & $<0.01$ & $<0.01$ & $<0.01$ & $<0.01$ & 0.04 \\
\hline Co & 0.48 & $<0.01$ & $<0.01$ & 0.6 & $<0.01$ & $<0.01$ & $<0.01$ & $<0.01$ & 0.04 \\
\hline $\mathrm{Cu}$ & 1.6 & 2.1 & 2.1 & 3.1 & 1.0 & 2.3 & 1.5 & 0.24 & 2.0 \\
\hline $\mathrm{Fe}$ & 1.2 & 1.3 & 2.0 & 5.8 & 100 & 75 & 7.0 & 4.0 & - \\
\hline
\end{tabular}




$\begin{array}{lccccccccc}\mathrm{K}, \% & 11.2 & 5.5 & 0.084 & 1.2 & 2.3 & 8.5 & 2.1 & 10.9 & - \\ \mathrm{Mg} & 54 & 12 & 1.3 & 2.0 & 950 & 560 & 57 & 78 & - \\ \mathrm{Mn} & 0.003 & <0.01 & <0.01 & <0.01 & <0.01 & <0.01 & 0.2 & 0.01 & - \\ \mathrm{Mo} & 28 & 35 & 0.7 & 2.4 & 31 & 28 & 56 & 37 & 0.5 \\ \mathrm{Na}, \% & 0.037 & 0.79 & 0.026 & 2.3 & 0.053 & 0.54 & 0.049 & 0.6 & - \\ \mathrm{Ni} & <0.01 & 1.3 & <0.01 & <0.01 & <0.01 & <0.01 & <0.01 & <0.01 & 0.4 \\ \mathrm{P} & 21 & 520 & 3.9 & 54 & 310 & 320 & 200 & 280 & - \\ \mathrm{Pb} & 0.3 & 3.0 & 3.5 & 6.0 & 3.0 & 4.3 & 1.7 & 2.3 & 0.5 \\ \mathrm{Si} & <0.01 & <0.01 & <0.01 & <0.01 & <0.01 & <0.01 & <0.01 & <0.01 & - \\ \mathrm{Sr} & 43 & 1.7 & 15 & 6.5 & 2.7 & 3.0 & 0.1 & 1.4 & - \\ \mathrm{Ti} & <0.01 & <0.01 & <0.01 & <0.01 & <0.01 & <0.01 & <0.01 & <0.01 & - \\ \mathrm{Zn} & 5.0 & 8.0 & 1.0 & 39 & 0.4 & 17 & 0.9 & 2.0 & 4.0 \\ \mathrm{Cl}{ }^{-}, \% & 13 & 2.9 & 0.2 & 6.5 & 0.33 & 5.8 & 0.18 & 5.1 & 0.08 \\ \mathrm{SO}_{4}^{2-}, \% & 0.32 & 4.0 & 0.053 & 3.0 & 0.6 & 3.6 & 0.73 & 4.3 & 0.033 \\ \mathrm{NO}_{3}{ }^{2}, \% & <0.01 & <0.01 & <0.01 & <0.01 & <0.01 & <0.01 & <0.01 & <0.01 & - \\ \mathrm{Total}^{2} & 35.1 & 33.8 & 1.0 & 34.6 & 8.4 & 35.6 & 7.5 & 36.7 & -\end{array}$

Dissolved

Solids, \%

$>1 \%$ - major; 0.1-1\% - minor; $<0.1$ - trace element

Failure of inert WAC

Table 5. Element species (\%) for water leachates from UK biomass ashes. 


\begin{tabular}{|c|c|c|c|c|c|c|c|c|}
\hline \multirow[b]{2}{*}{ Element species } & \multirow[b]{2}{*}{$\begin{array}{c}\text { S- } \\
\text { APCr }\end{array}$} & \multirow[b]{2}{*}{$\begin{array}{l}\text { PL1- } \\
\text { APCr }\end{array}$} & \multicolumn{2}{|c|}{ MBM } & \multicolumn{2}{|c|}{$\mathrm{PL} 2$} & \multicolumn{2}{|c|}{ PL3 } \\
\hline & & & BA & $\mathrm{APCr}$ & TA & $\mathrm{APCr}$ & $\mathrm{BA}$ & $\mathrm{APCr}$ \\
\hline $\mathrm{Na}^{+}$ & 99.95 & 99.21 & 99.99 & 99.87 & 99.99 & 99.32 & 99.94 & 99.64 \\
\hline $\mathrm{NaSO}_{4}^{-}$ & 0.05 & 0.79 & 0.01 & 0.13 & 0.01 & 0.68 & 0.06 & 0.36 \\
\hline $\mathrm{K}^{+}$ & 99.93 & 98.90 & 99.98 & 99.82 & 99.99 & 99.06 & 99.91 & 99.5 \\
\hline $\mathrm{KSO}_{4}^{-}$ & 0.07 & 1.10 & 0.02 & 0.18 & 0.01 & 0.94 & 0.09 & 0.5 \\
\hline $\mathrm{Ca}^{2+}$ & 64.87 & 50.12 & 82.69 & 71.76 & 61.98 & 72.11 & 46.91 & 71.51 \\
\hline $\mathrm{CaOH}^{+}$ & 31.94 & 2.21 & 16.97 & 20.59 & 37.8 & 15.33 & 19.95 & 1.95 \\
\hline $\mathrm{CaPO}_{4}^{-}$ & 2.46 & 36.65 & 0.02 & 5.40 & 0.13 & 0.81 & 32.49 & 19.18 \\
\hline $\mathrm{CaHPO}_{4}{ }^{0}$ & 0 & 0.04 & 0 & 0 & 0 & 0 & 0 & 0.04 \\
\hline $\mathrm{CaSO}_{4}{ }^{0}$ & 0.72 & 10.99 & 0.32 & 2.25 & 0.11 & 11.75 & 0.65 & 7.35 \\
\hline $\mathrm{Mg}^{2+}$ & 8.31 & 31.06 & 18.11 & 13.36 & 6.85 & 16.92 & 8.78 & 47.97 \\
\hline $\mathrm{MgOH}^{+}$ & 91.14 & 30.07 & 81.81 & 84.77 & 93.12 & 79.54 & 82.76 & 28.77 \\
\hline $\mathrm{MgHPO}_{4}{ }^{0}$ & 0 & 0.03 & 0 & 0 & 0 & 0 & 0 & 0.03 \\
\hline $\mathrm{MgPO}_{4}^{-}$ & 0.43 & 30.80 & 0 & 1.37 & 0.02 & 0.26 & 8.31 & 17.43 \\
\hline $\mathrm{MgSO}_{4}{ }^{0}$ & 0.11 & 8.04 & 0.08 & 0.5 & 0.01 & 3.27 & 0.14 & 5.82 \\
\hline $\mathrm{Cl}^{-}$ & 100 & 100 & 100 & 100 & 100 & 100 & 100 & 100 \\
\hline $\mathrm{SO}_{4}{ }^{2-}$ & 98.95 & 99.19 & 0 & 99.54 & 99.64 & 99.00 & 99.78 & 98.47 \\
\hline $\mathrm{PO}_{4}{ }^{3-}$ & 44.10 & 13.97 & 0.56 & 21.71 & 12.34 & 19.73 & 65.22 & 8.44 \\
\hline $\mathrm{HPO}_{4}{ }^{2-}$ & 8.76 & 56.15 & 0.45 & 9.96 & 1.89 & 12.19 & 17.81 & 59.3 \\
\hline $\mathrm{Fe}(\mathrm{OH})_{3}{ }^{0}$ & 0.02 & 0.29 & 0.06 & 0.04 & 0.02 & 0.05 & 0.02 & 0.48 \\
\hline $\mathrm{Fe}(\mathrm{OH})_{4}^{-}$ & 99.98 & 99.71 & 99.94 & 99.96 & 99.98 & 99.95 & 99.98 & 99.52 \\
\hline $\mathrm{Al}(\mathrm{OH})_{4}^{-}$ & 100 & 100 & 100 & 100 & 100 & 100 & 100 & 100 \\
\hline $\mathrm{ZnOH}^{+}$ & 0 & 0.01 & 0 & 0 & 0 & 0 & 0 & 0.03 \\
\hline $\mathrm{Zn}(\mathrm{OH})_{2}{ }^{0}$ & 2.39 & 43.61 & 11.23 & 6.47 & 1.65 & 9.36 & 3.44 & 57.16 \\
\hline $\mathrm{Zn}(\mathrm{OH})_{3}^{-}$ & 43.20 & 52.56 & 65.40 & 58.84 & 37.64 & 63.06 & 49.31 & 41.07 \\
\hline $\mathrm{Zn}(\mathrm{OH})_{4}{ }^{2-}$ & 54.41 & 3.82 & 23.37 & 34.69 & 60.72 & 27.58 & 47.25 & 1.74 \\
\hline $\mathrm{Cu}(\mathrm{OH})_{2}{ }^{0}$ & 52.94 & 97.55 & 86.14 & 76.82 & 43.09 & 83.40 & 62.42 & 98.58 \\
\hline $\mathrm{Cu}(\mathrm{OH})_{3}^{-}$ & 18.20 & 2.24 & 9.56 & 13.30 & 18.78 & 10.71 & 17.03 & 1.35 \\
\hline $\mathrm{Cu}(\mathrm{OH})_{4}^{2-}$ & 28.86 & 0.2 & 4.3 & 9.87 & 38.13 & 5.90 & 20.54 & 0.07 \\
\hline $\mathrm{PbOH}^{+}$ & 0 & 0.08 & 0 & 0 & 0 & 0 & 0 & 0.26 \\
\hline $\mathrm{Pb}(\mathrm{OH})_{2}{ }^{0}$ & 0.08 & 10.02 & 0.76 & 0.32 & 0.05 & 0.56 & 0.13 & 19.15 \\
\hline $\mathrm{Pb}(\mathrm{OH})_{3}^{-}$ & 5.20 & 43.86 & 16.09 & 10.47 & 4.11 & 13.58 & 6.73 & 49.96 \\
\hline $\mathrm{Pb}(\mathrm{OH})_{4}^{2-}$ & 94.72 & 46.03 & 83.14 & 89.21 & 95.84 & 85.86 & 93.15 & 30.63 \\
\hline
\end{tabular}


Table 6. Saturation Indices (SI) for water leachates from UK biomass ashes.

\begin{tabular}{|c|c|c|c|c|c|c|c|c|}
\hline \multirow[b]{2}{*}{ Element species } & \multirow[b]{2}{*}{$\begin{array}{c}\mathrm{S}- \\
\mathrm{APCr}\end{array}$} & \multirow[b]{2}{*}{$\begin{array}{l}\text { PL1- } \\
\text { APCr }\end{array}$} & \multicolumn{2}{|c|}{ MBM } & \multicolumn{2}{|c|}{ PL2 } & \multicolumn{2}{|c|}{ PL3 } \\
\hline & & & BA & $\mathrm{APCr}$ & BA & $\mathrm{APCr}$ & BA & $\mathrm{APCr}$ \\
\hline Brucite $\left(\mathrm{Mg}(\mathrm{OH})_{2}\right)$ & 2.5 & 0.3 & 0.4 & -0.8 & 2.9 & 2.1 & 1.4 & -0.2 \\
\hline Cupric Ferrite $\left(\mathrm{CuFe}_{2} \mathrm{O}_{4}\right)$ & 2.3 & 5.0 & 4.0 & 4.7 & 5.6 & 7.3 & 4.1 & 6.1 \\
\hline Goethite (FeOOH) & 2.2 & 3.4 & 2.9 & 3.2 & 4.0 & 4.5 & 3.1 & 11 \\
\hline Hematite $\left(\mathrm{Fe}_{2} \mathrm{O}_{3}\right)$ & 6.4 & 8.7 & 7.8 & 8.3 & 10 & 11 & 8.1 & 4.3 \\
\hline $\begin{array}{l}\text { Hydroxyapatite } \\
\left(\mathrm{Ca}_{5}\left(\mathrm{PO}_{4}\right)_{3}(\mathrm{OH})\right)\end{array}$ & -4.7 & -2.3 & 3.3 & 3.0 & 0.98 & -5.3 & -0.64 & 1.1 \\
\hline $\mathrm{Pb}(\mathrm{OH})_{2}$ & -3.0 & 0.13 & -0.92 & -1.1 & -2.2 & -0.97 & -2.0 & 0.30 \\
\hline $\mathrm{Cu}(\mathrm{OH})_{2}$ & -2.8 & -2.5 & -2.5 & -2.5 & -3.1 & -2.5 & -2.8 & -3.4 \\
\hline Tenorite (CuO) & -1.8 & -1.4 & -1.5 & -1.4 & -2.1 & -1.5 & -1.8 & -2.4 \\
\hline $\mathrm{Zn}(\mathrm{OH})_{2}$ & -3.3 & -1.9 & -3.4 & -2.0 & -4.6 & -2.2 & -3.9 & -2.4 \\
\hline $\mathrm{ZnO}$ & -3.1 & -1.7 & -3.2 & -1.8 & -4.4 & -2.0 & -3.7 & -2.2 \\
\hline
\end{tabular}

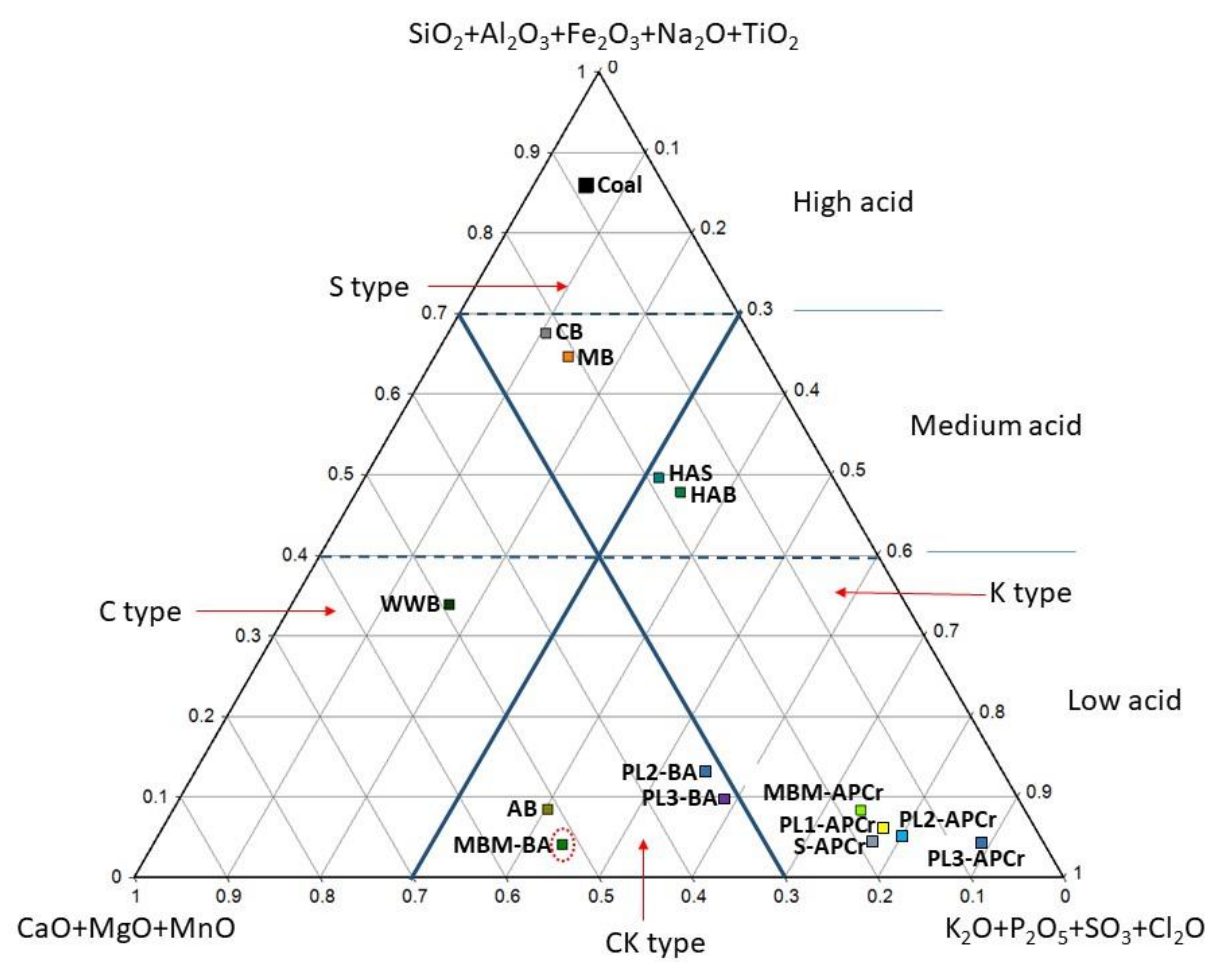

Figure 1. Positions of the eight UK biomass ashes compared with other biomass ashes and fossil fuels in the chemical classification system of biomass ashes based on $[5,6,9,10]$. Abbreviations: $\mathrm{C}$ - coal; WWB - wood and woody biomass; HAB - herbaceous and agricultural biomass; HAS - herbaceous and agricultural straw; $A B$ - animal biomass; $\mathrm{MB}$ - mixture of biomass; $\mathrm{CB}$ - contaminated biomass. 


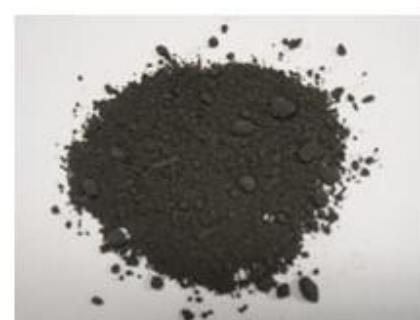

S-APCr

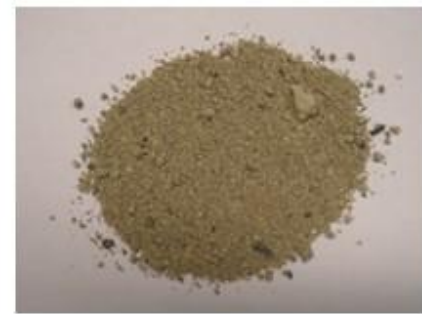

PL2-BA

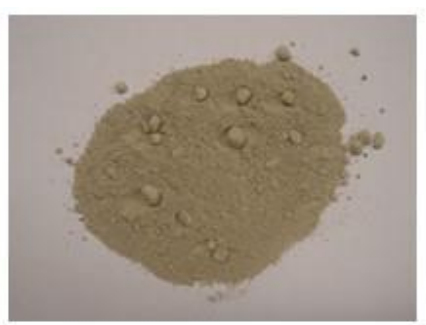

PL1-APCr

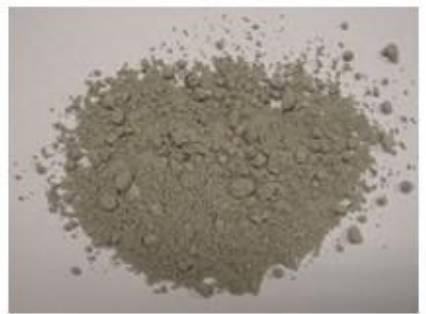

PL2-APCr

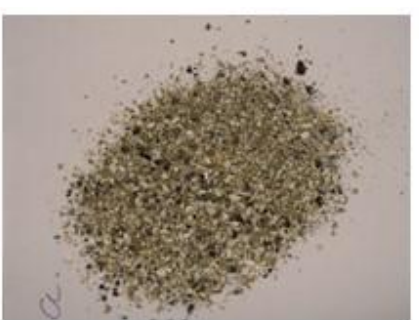

MBM-BA

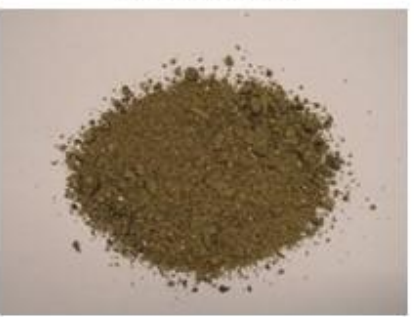

PL3-BA

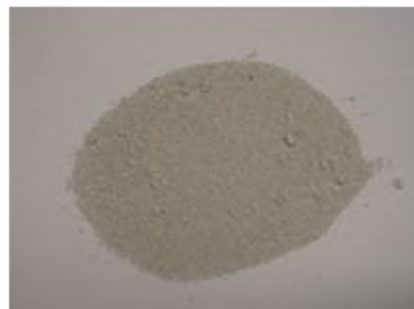

MBM-APCr

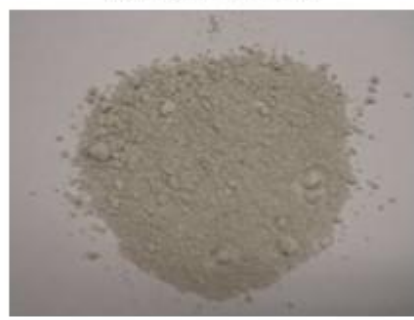

PL3-APCr
534
535

536

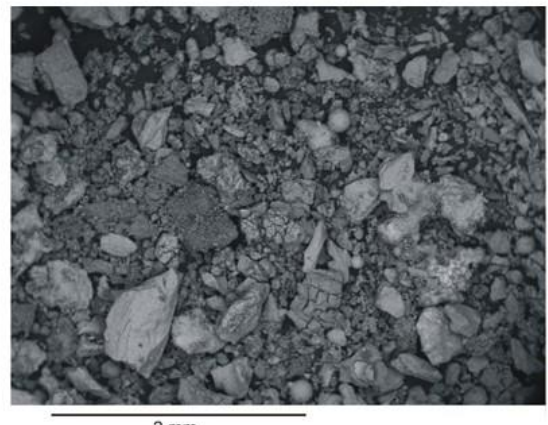

MBM-BA

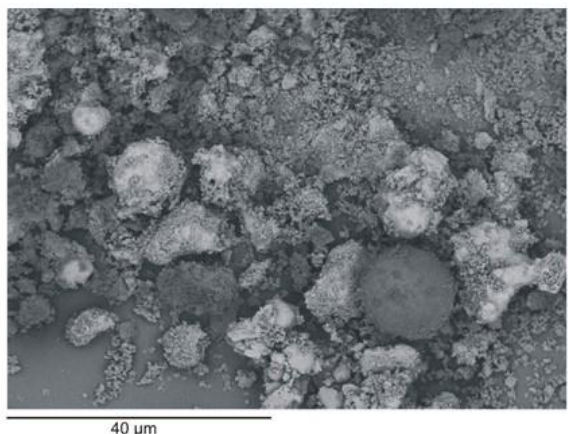

PL2-BA

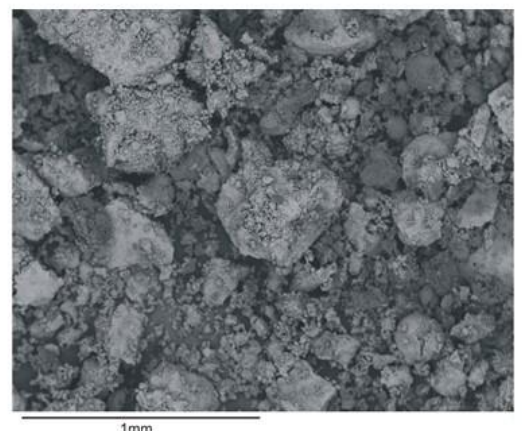

PL3-BA

Fig 3. Scanning electron microscope images of the biomass bottom ashes.

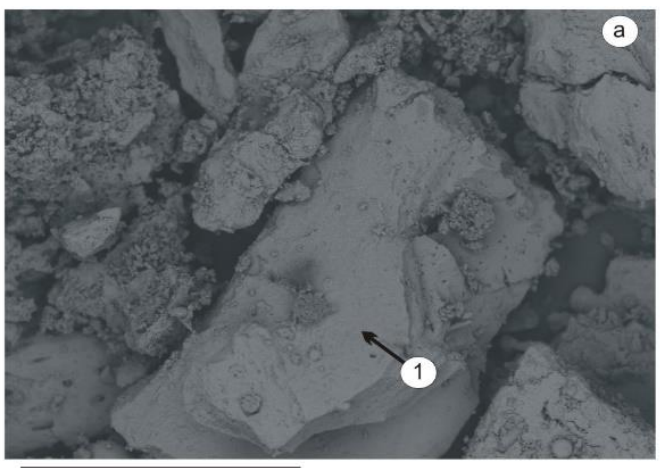

$600 \mu \mathrm{m}$

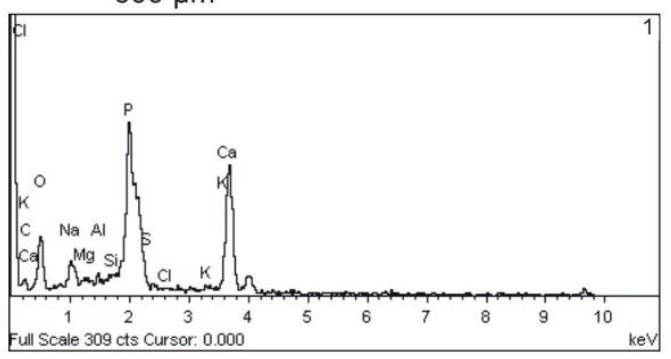

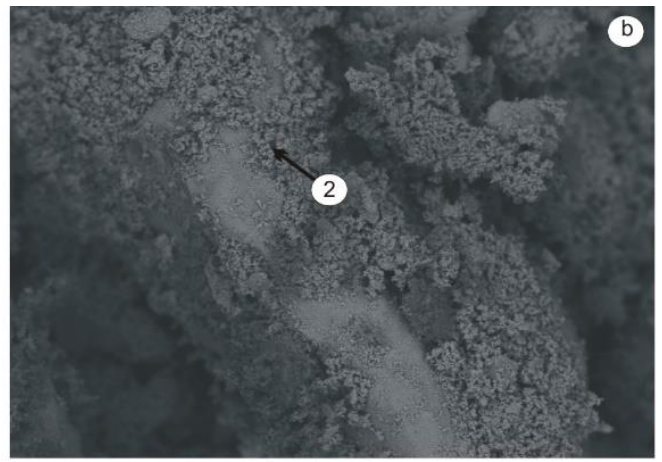

$200 \mu \mathrm{m}$

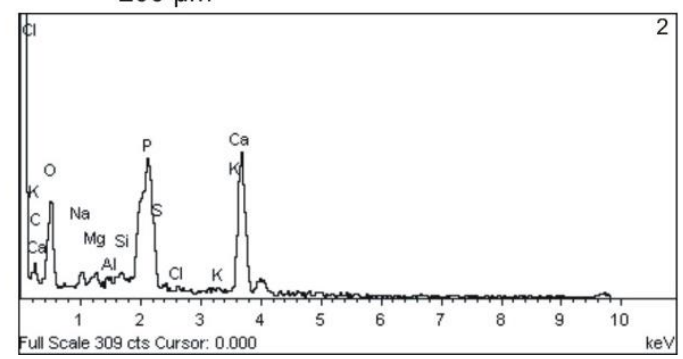

Figure 4. Scanning electron microscope images of unshaped particle (a) and associated fine materials (b) with EDS spectra. 


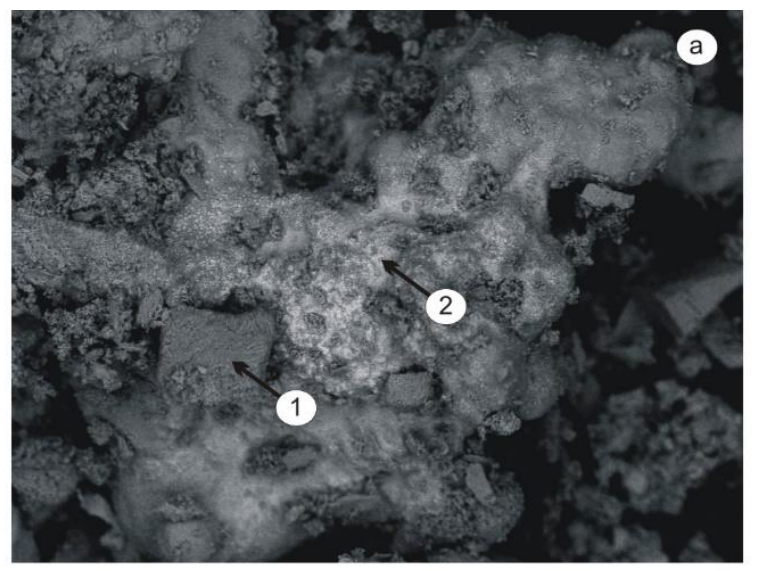

$300 \mu \mathrm{m}$

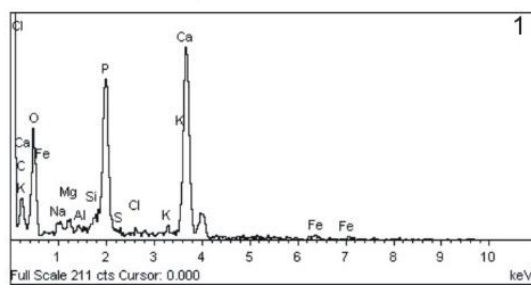

Figure 5. Scanning electron microscope images of unshaped particle (a) and aggregate (b) with EDS spectra.

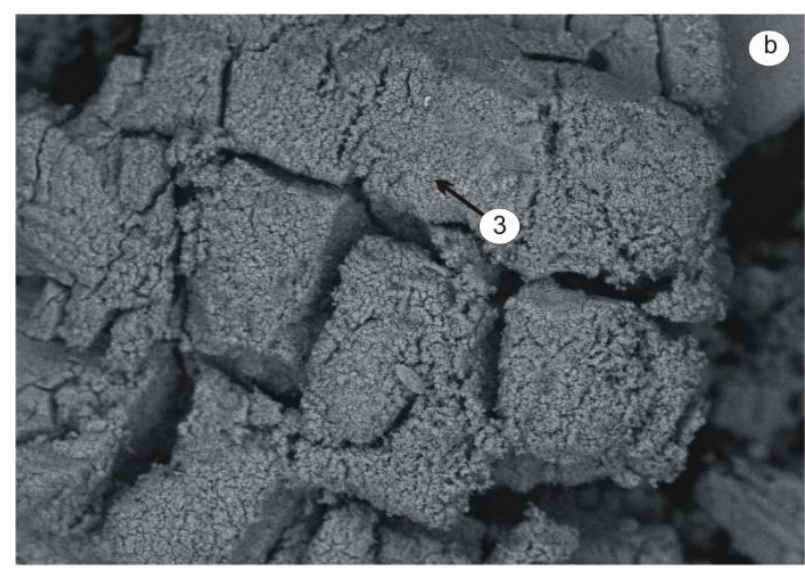

$100 \mu \mathrm{m}$
546

547

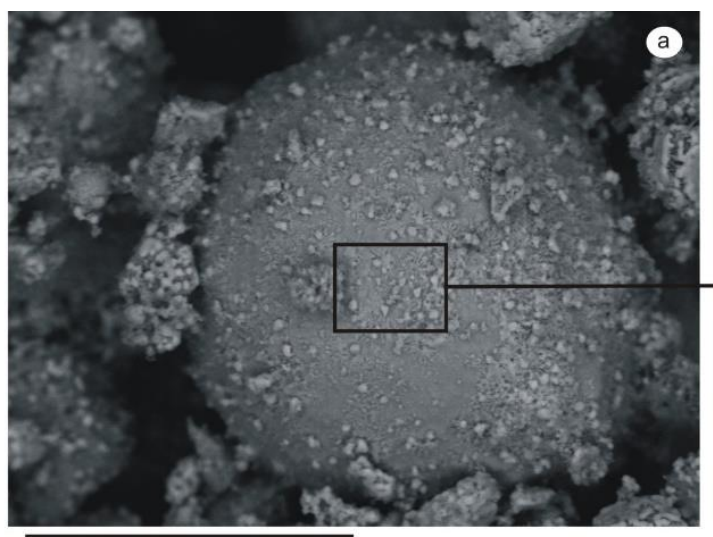

$70 \mu \mathrm{m}$
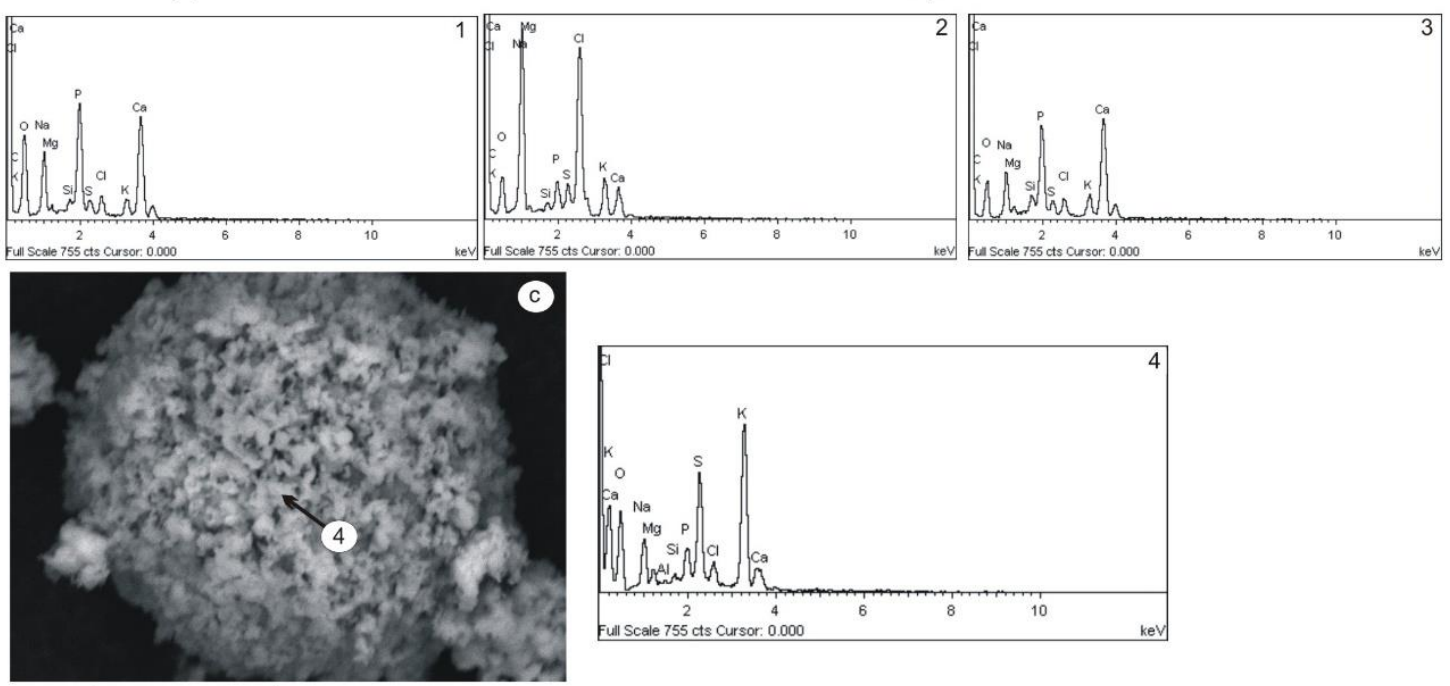

$10 \mu \mathrm{m}$

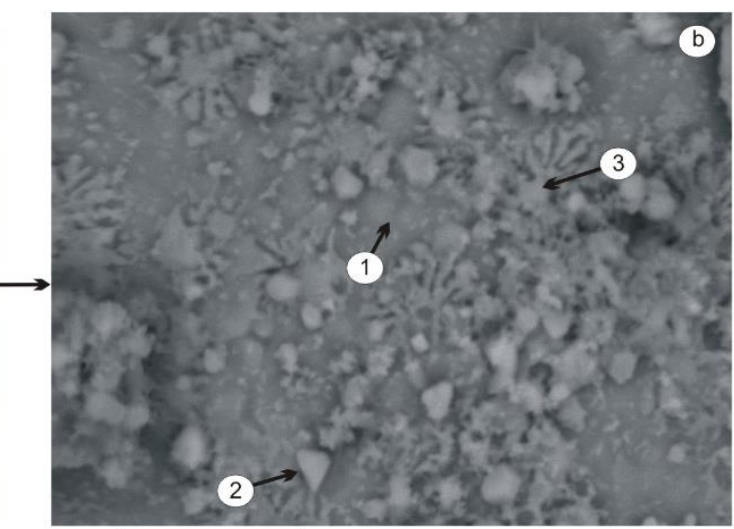

$10 \mu \mathrm{m}$

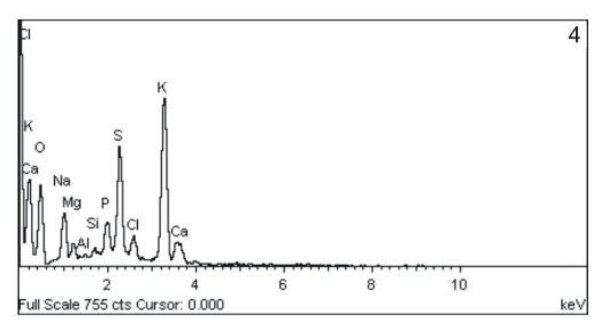

Figure 6. Scanning electron microscope images of spherical particle from biomass bottom ashes and EDS spectra. 

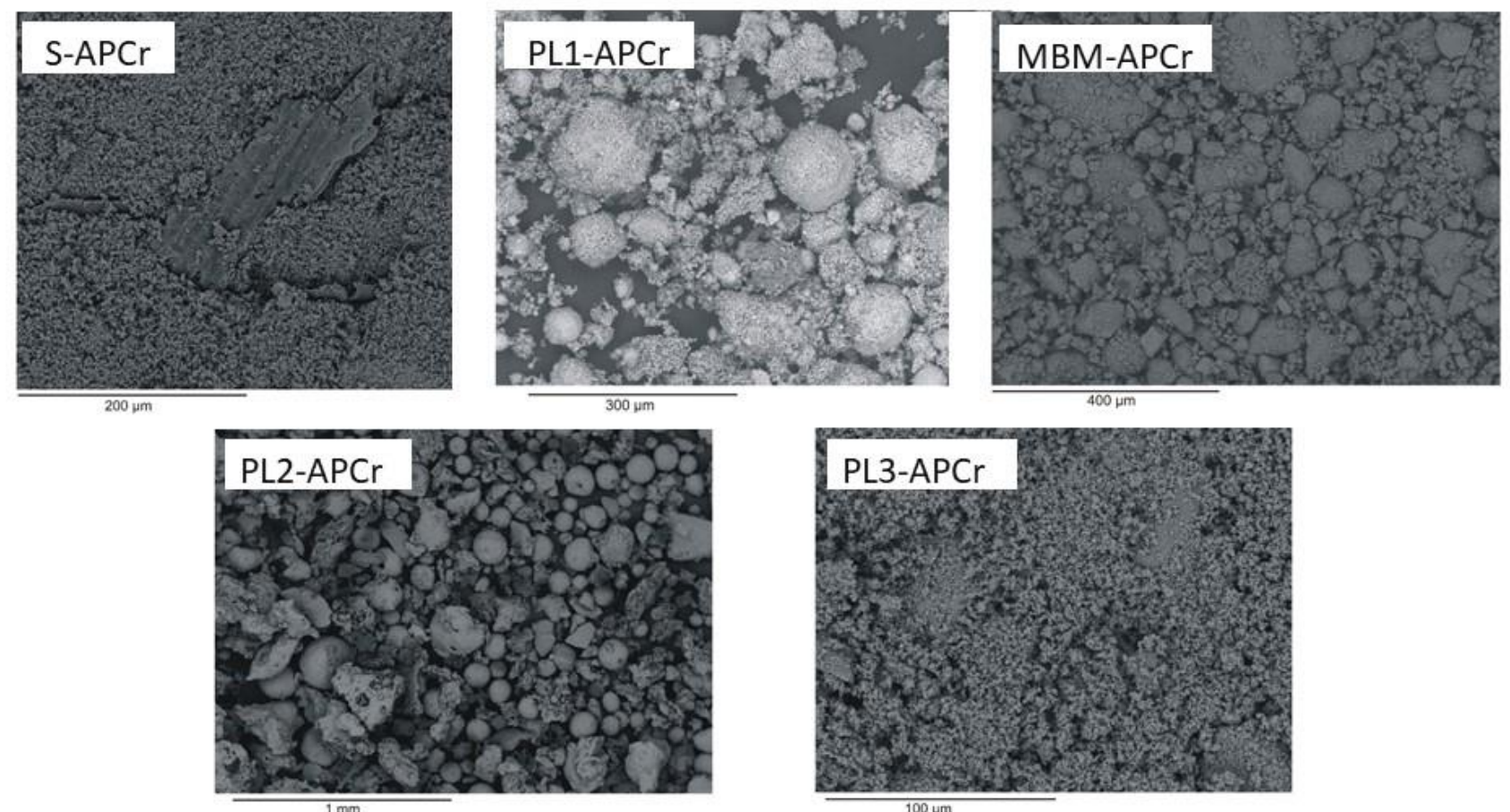

552

553

554

Fig 7. Scanning electron microscope images of the biomass APC residues.

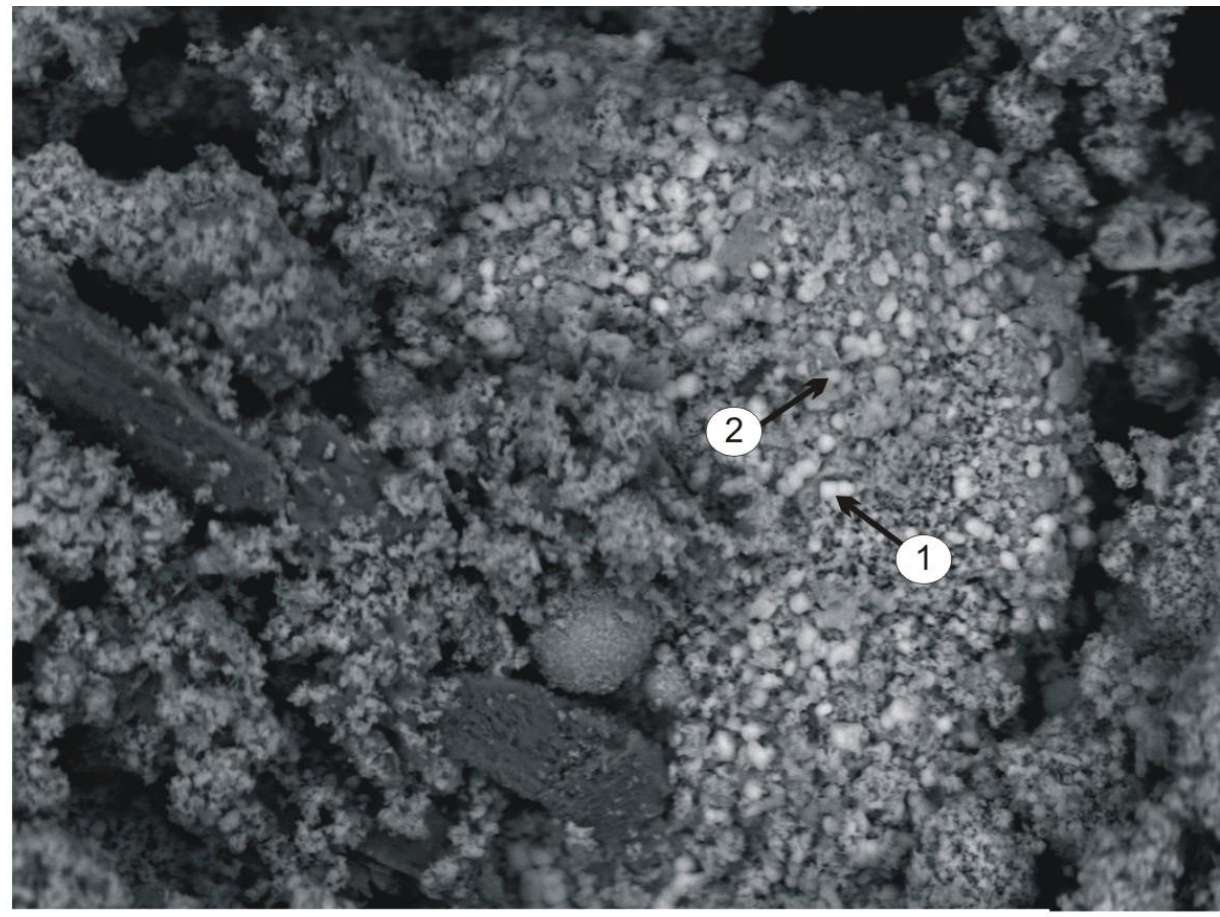

$70 \mu \mathrm{m}$

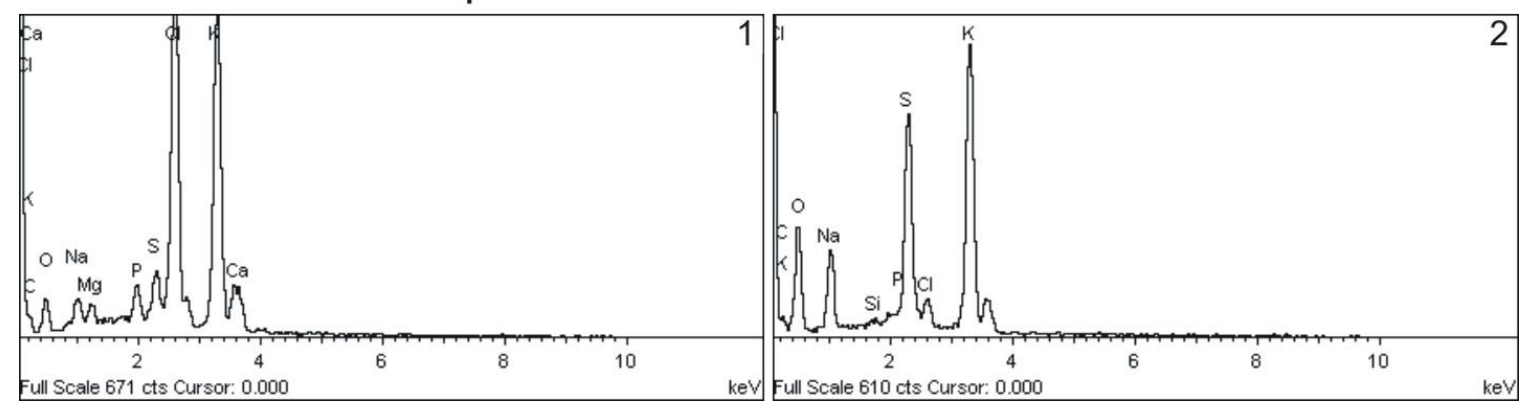

556 Figure 8. Scanning electron microscope image of unshaped and spherical particles covered by fine 557 phases. 

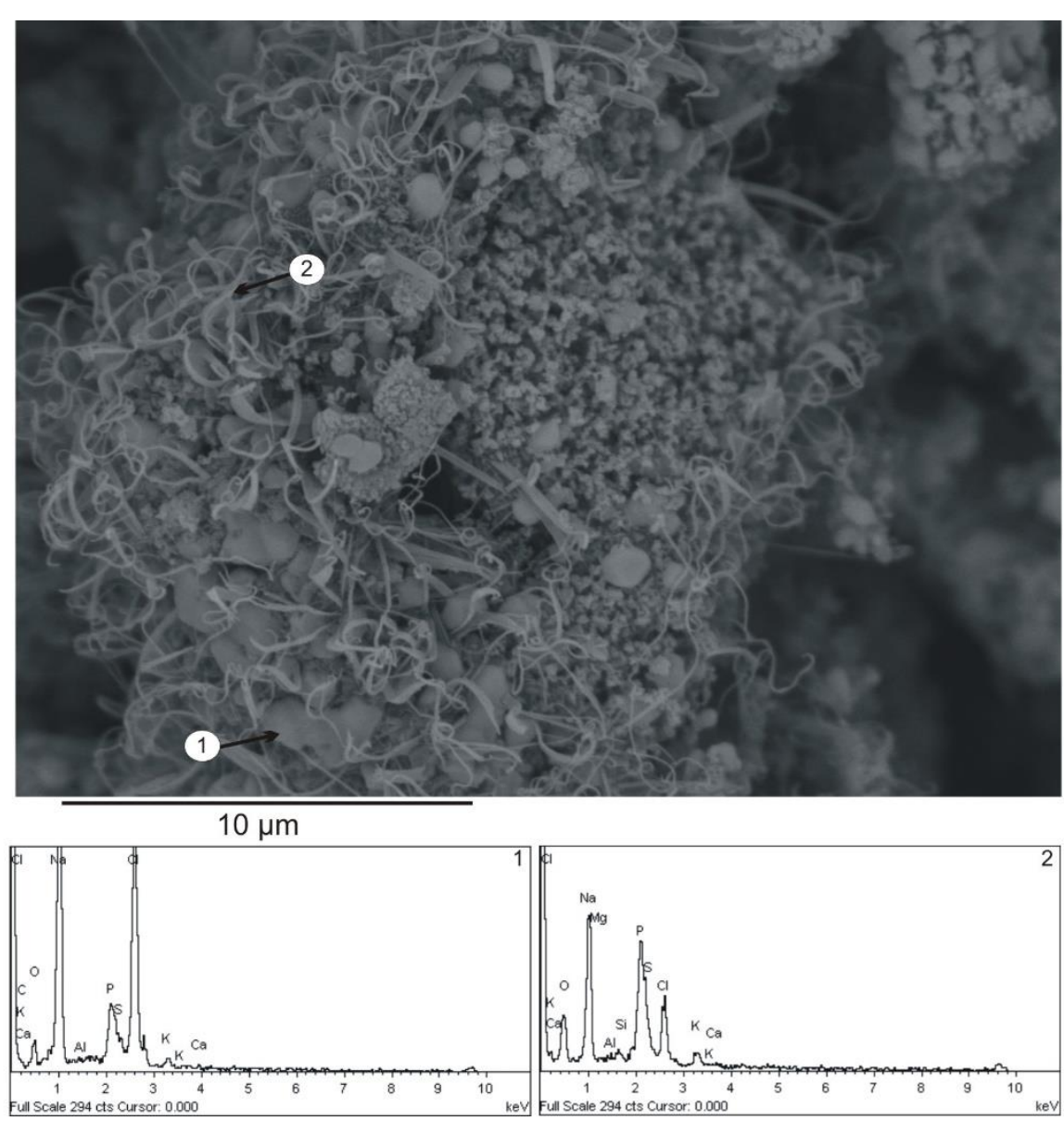

Figure 9. Scanning electron microscope image of aggregate consisting of different fine phases.
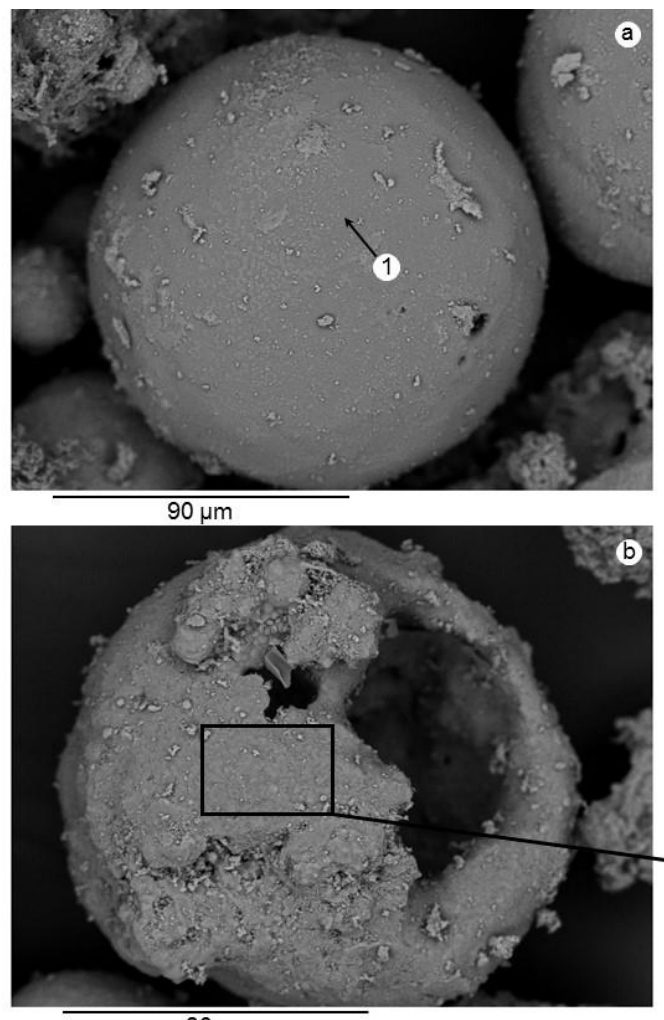

$80 \mu \mathrm{m}$

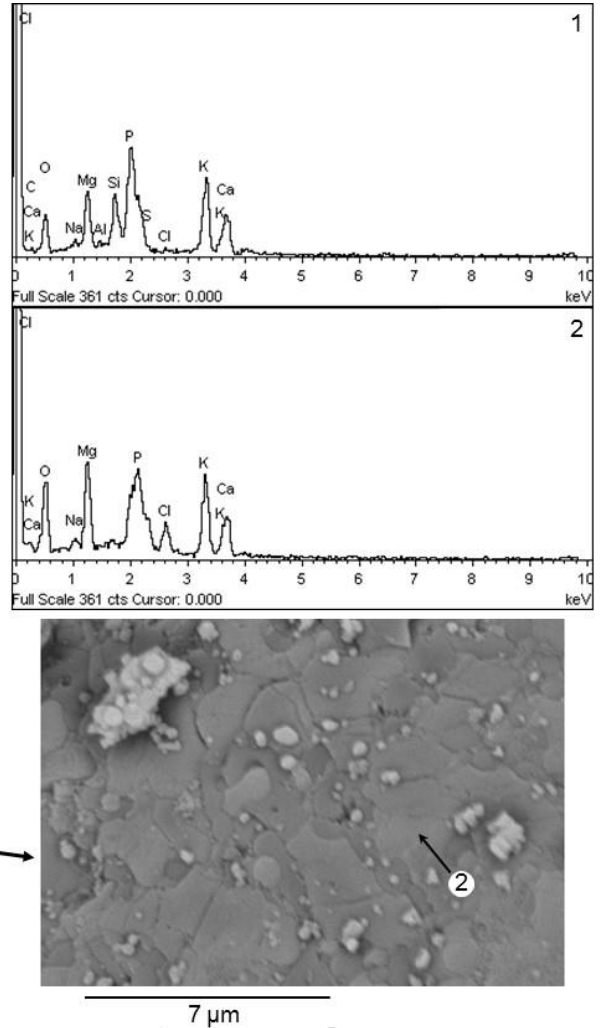

Figure 10. Scanning electron microscope images of spherical particles from PL2-APCr. 


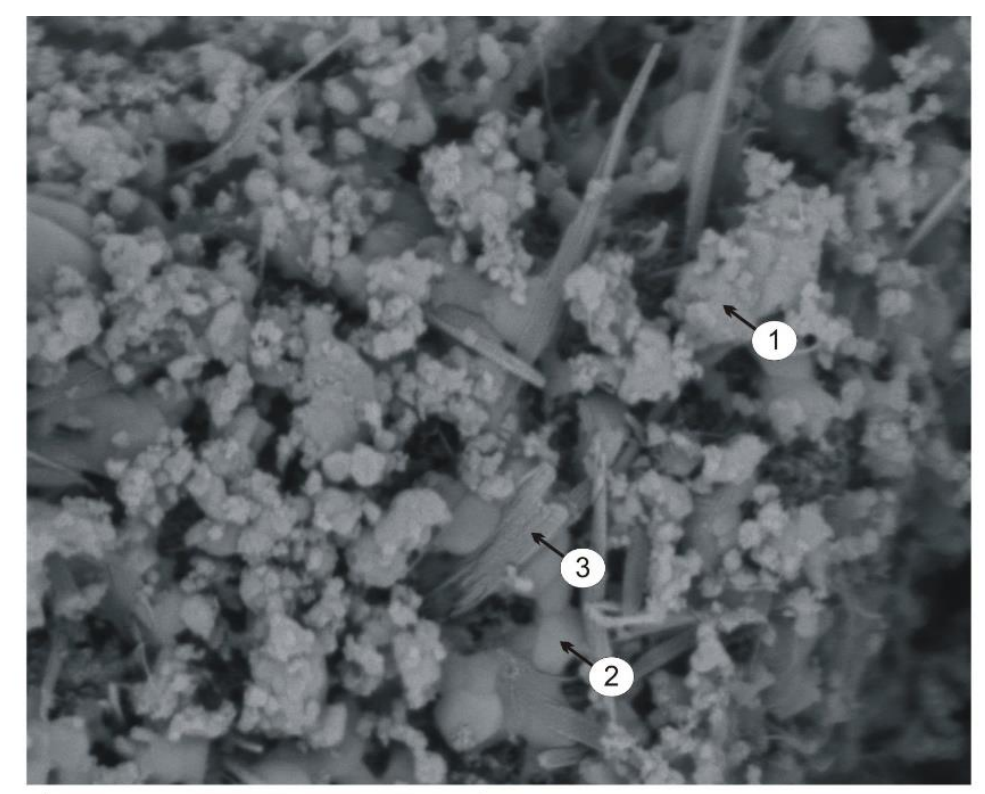

$10 \mu \mathrm{m}$ 